\title{
Stem cell biomarkers in chronic myeloid leukemia
}

\author{
Xiaoyan Jiang ${ }^{\mathrm{a}, \mathrm{b}}$, Yun Zhao ${ }^{\mathrm{a}}$, Donna Forrest ${ }^{\mathrm{c}}$, Clayton Smith ${ }^{\mathrm{a}, \mathrm{c}}$, Allen Eaves ${ }^{\mathrm{a}, \mathrm{c}, \mathrm{d}}$ and \\ Connie Eaves ${ }^{\mathrm{a}, \mathrm{b}, \mathrm{c}, \mathrm{d}, *}$ \\ ${ }^{a}$ Terry Fox Laboratory, British Columbia Cancer Agency, Vancouver, BC, Canada V5Z 1 L3 \\ ${ }^{\mathrm{b}}$ Department of Medical Genetics, University of British Columbia, Vancouver, BC, Canada V5Z 1L3 \\ ${ }^{\mathrm{c}}$ Department of Medicine, University of British Columbia, Vancouver, BC, Canada V5Z 1L3 \\ ${ }^{\mathrm{d}}$ Department of Pathology and Laboratory Medicine, University of British Columbia, Vancouver, BC, Canada V5Z \\ $1 L 3$
}

\begin{abstract}
Chronic myeloid leukemia (CML) is a clonal multi-step myeloproliferative disease that is initially produced and ultimately sustained by a rare subpopulation of $B C R-A B L^{+}$cells with multi-lineage stem cell properties. These $B C R-A B L^{+} C M L$ stem cells are phenotypically similar to normal hematopoietic stem cells which are also maintained throughout the course of the disease at varying levels in different patients. Defining the unique properties of the leukemic stem cells that produce the chronic phase of CML has therefore had to rely heavily on access to samples from rare patients in which the stem cell compartment is dominated by leukemic elements. Here we review past and ongoing approaches using such samples to identify biologically and clinically relevant biomarkers of $B C R-A B L^{+}$stem cells that explain their unusual biology and that may help to design, or at least predict, improved treatment responses in CML patients. These studies are of particular interest in light of recent evidence that chronic phase CML stem cells are not only innately resistant to imatinib mesylate and other drugs that target the BCR-ABL oncoprotein, but are also genetically unstable.
\end{abstract}

Keywords: Hematopoietic stem cells, chronic myeloid leukemia, imatinib, BCR-ABL-targeted therapies, stem cell biomarkers, drug resistance

\section{Introduction}

Chronic myeloid leukemia (CML) is a myeloproliferative disorder that is usually first identified clinically by symptoms that are caused by an inappropriately increased production of granulocytes and monocytes. Biologically, CML is now recognized to represent a multi-step, multi-lineage, clonal hematopoietic disorder that is initiated and propagated by a rare population of CML stem cells that have acquired a $B C R-A B L$ fusion gene. During the chronic phase $(\mathrm{CP})$ of the disease, these CML stem cells possess many properties typical of normal hematopoietic stem cells (HSCs), in-

${ }^{*}$ Corresponding author: Dr. Connie Eaves, Terry Fox Laboratory, 675 West $10^{\text {th }}$ Avenue, Vancouver, BC, V5Z 1L3, Canada. Tel.: +1 604675 8122; Fax: +1 604877 0712; E-mail: ceaves@bccrc.ca. cluding an ability to differentiate into almost all blood cell types.

In most CML patients, the $B C R-A B L$ fusion gene reflects a simple reciprocal translocation between the long arms of chromosomes 9 and 22, resulting in the formation of the hallmark Philadelphia $(\mathrm{Ph})$ chromosome. The $B C R-A B L$ fusion gene encodes a chimeric oncoprotein that displays constitutively activated tyrosine kinase activity and is inappropriately localized in the cytoplasm. These features deregulate cellular proliferation and apoptosis control through effects on multiple signaling pathways [1,2]. Direct evidence that the $B C R-A B L$ rearrangement is a key transforming event in the generation of CML has been provided by gene transfer experiments $[3,4]$ and the ability of specific inhibitors of the $B C R-A B L$ oncoprotein to induce remissions in patients [5-9]. 
An understanding of the role of the $B C R-A B L$ oncogene in the genesis and maintenance of CML has led to the development of novel "targeted" therapies that selectively inhibit the tyrosine kinase activity of $B C R$ $A B L$-encoded fusion proteins. The first of these tyrosine kinase inhibitors was imatinib mesylate (IM), also known as Gleevec (Novartis Pharmaceuticals). Clinical trials have shown "complete" cytogenetic response rates of $87 \%$ in CP CML patients treated with IM for 60 months with $93 \%$ progression-free survival [10]. Nevertheless, despite these remarkable initial responses to IM therapy, molecular remissions are rare and the emergence of IM-resistant subclones continues to pose a significant clinical problem [11,12]. Indeed, approximately $10-15 \%$ of patients with early CP CML will either present with or later show the appearance of IM-resistant cells. Some of these patients respond to higher doses of IM [13] or to second generation tyrosine kinase inhibitors like dasatinib (Sprycel, Bristol Myers Squibb) or nilotinib (Tasigna, Novartis). However, a proportion does not and the disease in this latter group might be better managed by treatment with an intensive conditioning regimen and an appropriately matched transplant of normal HSCs.

In most patients, loss of responsiveness to IM appears gradually - as indicated by a slow increase in the proportion of $B C R-A B L^{+} / \mathrm{Ph}^{+}$cells detectable in the marrow (and/or blood) over a period of several months. However, in a small group ( $1 \%$ to $2 \%$ ) of IM-treated CP patients, blast phase disease appears within 3 months of a previously documented complete cytogenetic remission $[14,15]$ and the salvage rate for this important subgroup, even with myeloablative treatments supported by an allogeneic transplant, is low [16]. Thus, there is an urgent need to develop prognostic tests to identify those patients who will not respond to IM and for whom alternative treatments would be important to initiate before disease progression occurs.

In the pre-IM era, several clinical and laboratory features allowed responses to existing therapies to be predicted. The Sokal score, initially developed to predict response to busulfan [17], still retains some predictive value for IM therapy. Patients with high-risk Sokal scores have a $69 \%$ chance of achieving a complete cytogenetic remission within 12 months, compared to $82 \%$ and $89 \%$ for intermediate and low-risk scores, respectively. However, once a complete cytogenetic remission has been obtained, the Sokal score loses its prognostic importance and the progression-free survival for all 3 groups remains equal. Therefore, even a high-risk Sokal score at diagnosis does not, on its own, justify the adoption of an alternative front-line therapy until after an initial trial of IM.

The appearance of karyotypic abnormalities in addition to the $\mathrm{Ph}$ chromosome has also been associated with an adverse prognosis and is usually accompanied by other manifestations of more advanced disease. However, with the higher doses of IM now in use, evidence of clonal evolution alone has not been associated with an inferior outcome [18,19]. Similarly, deletions involving the derivative 9 chromosome that were predictive of a poor outcome to interferon [20] have not been found to have similar significance for patients receiving IM and preliminary reports suggest little or no relationship of this parameter to the achievement or durability of an IM response [21,22].

The failure of these historical clinical and laboratory parameters to identify patients who are likely to be unresponsive to $B C R$ - $A B L$-targeted therapies has focused attention on a need for new biomarkers that can serve this purpose. A logical starting point is the leukemic stem cell compartment of these patients, since it is the number and properties of these cells that ultimately determine the growth characteristics and evolution of the leukemic clone, as well as the size of the residual normal HSC population upon which autologous regeneration of the hematopoietic system depends.

\section{Biologic definition of CML stem cells}

Much evidence indicates that the leukemic clone in patients with CML originates in a multi-potent HSC whose ability to generate normal blood cell progeny is not detectably perturbed by the acquisition of a $B C R$ $A B L$ fusion gene, although the number of differentiating cells produced from the small pool of $B C R-A B L^{+}$ stem cells is markedly altered. As a result, during the CP of the disease, the same hierarchy of primitive and mature compartments of cells that characterize normal hematopoiesis can be readily discerned within the expanding leukemic clone and these differentiating "leukemic" cells are functionally, morphologically, and phenotypically almost indistinguishable from their normal counterparts [23,24] (see also Fig. 1). Accumulating evidence indicates that this hierarchy is established in normal hematopoietic cells by mechanisms that progressively restrict hematopoietic differentiation and proliferative potential in a highly co-ordinated fashion that spans many cell generations [25-28]. Sequential stages within this hierarchy can thus be distinguished both by the maximum number and types of 


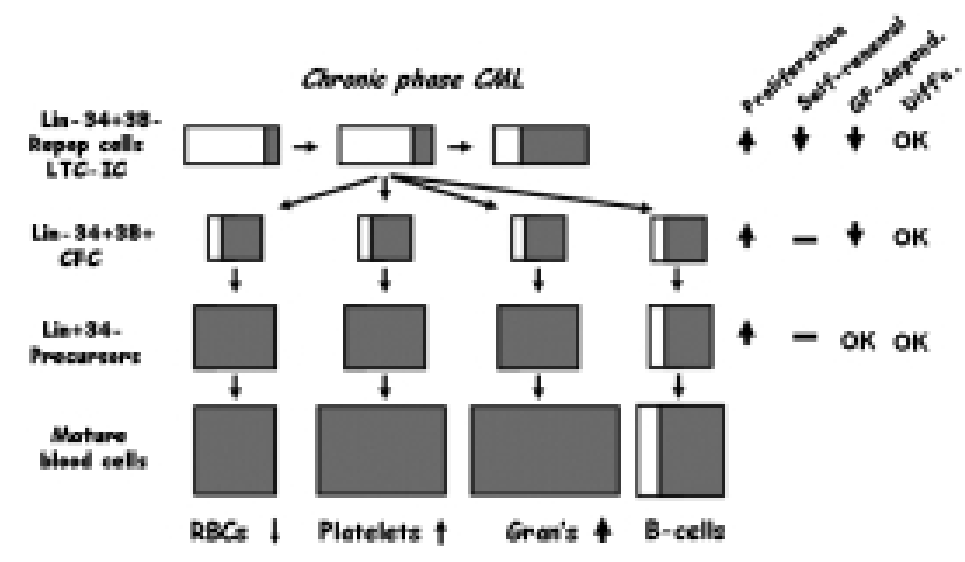

Fig. 1. Schema showing the relative sizes of different subpopulations of normal and leukemic cells present in CP patients. The shared phenotypes and functional endpoints that identify similar types of normal and leukemic elements are listed on the left side. The boxes in the central part of the figure illustrate diagrammatically the relative numbers of each of these that are normal (white) and leukemic (grey). As shown, dominance of the system by CML cells is typically achieved only in the later stages of differentiation. The very slow rate at which the CML stem cells accumulate in spite of their competitive advantage at later stages of differentiation may be explained, at least in part, by the activation in the most primitive CML cells of an autocrine IL-3/G-CSF mechanism that reduces their growth factor dependence [67]. This, in turn, allows the leukemic cells at intermediate stages of differentiation to amplify but, at the stem cell level, this effect may be offset by a decreased self-renewal ability caused by same autocrine growth factors (as summarized on the right hand side of the schema). Diff'n. = differentiation; GF depend. = growth factor dependence.

mature progeny produced when the cells are optimally stimulated either in vitro or in vivo and by their corresponding phenotypic profiles [23,29].

Normal human HSCs are identified by their ability to repopulate sublethally irradiated immunodeficient (e.g., nonobese diabetic severe combined immunodeficiency, NOD/SCID) mice with both lymphoid and myeloid progeny - indicative of their multipotent status as well as their in vivo regenerative activity. Limiting dilution approaches can then be applied to quantify their numbers using endpoints that incorporate all of these features [30,31]. Accordingly, such cells are often described operationally as NOD/SCIDrepopulating cells. At least some of these cells can also generate multipotent progeny with similar secondary NOD/SCID mouse repopulating activity - indicative of their possession of some self-renewal potential. Mice with even greater immunodeficiencies (e.g., resulting from the additional inactivation of either the $\beta 2$-microglobulin gene or the gene for the $\gamma$ chain of the interleukin-2 [IL-2] receptor, or by injection of anti-asialo GM1 or anti-CD122 antibodies that also the residual target NK cells present in NOD/SCID mice) show selectively enhanced efficiency of engraftment by downstream multipotent human hematopoietic cells with short term repopulating activity [32-34]. However, these latter cells lack sustained repopulating activity and are also unable to generate progeny that can repopulate secondary NOD/SCID recipients. These features suggest that many of the cells able to repopulate more permissive strains of immunodeficient mice for periods of 4-20 weeks are not equivalent to murine cells identified as HSCs on the basis of their sustained selfrenewal potential (Fig. 2 - sequential RC's detected in mice) [35].

At the other end of the spectrum are the various lineages of terminally differentiating blood cells. These cells already display some recognizable features of the particular lineage they belong to and typically undergo a small number of amplifying divisions before their maturation is complete. Intermediate between the terminally differentiating cells and the HSC compartment are so-called "progenitor" cells that lack overt morphological features of a particular lineage but are readily detected and quantified by their ability to generate colonies of from 8 to $\sim 10^{5}$ mature blood cells when plated in a semi-solid medium containing an appropriate cocktail of growth factors. Cells that can generate colony-forming cells (CFCs) in the presence of stromal feeder layers in vitro for at least 5 weeks represent a more primitive compartment than most CFCs and, based on their mode of assay, are referred to as longterm culture-initiating cells (LTC-ICs) [23]. Some LTC-ICs are clearly not HSCs, but the extent to which these 2 operationally defined cell types may overlap is not yet clear [29].

In patients with $\mathrm{CP} C \mathrm{CML}, B C R-A B L^{+} / \mathrm{Ph}^{+} \mathrm{CFCs}$, LTC-ICs and NOD/SCID repopulating cells are detect- 


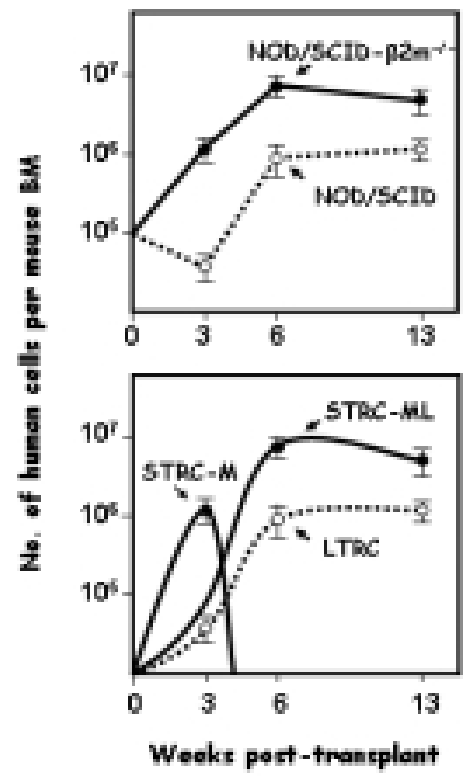

Fig. 2. Different patterns of regenerated human hematopoietic cells in mice with variable immunodeficiencies reflect different engraftment efficiencies of human cells with short and long term repopulating activities. As shown in the upper panel, transplants of bulk CD34+ human cells produce more progeny and faster in NOD/SCID- $\beta 2$-microglobulin null mice (solid line) as compared to standard NOD/SCID hosts (dotted line). Experiments with more purified cell transplants have demonstrated that the increased output of human cells obtained in the more NK-deficient NOD/SCID- $\beta 2$-microglobulin null mice reflects the additional activity of 2 types of short term repopulating cells (STRCs) that do not engraft NOD/SCID mice. One of these STRC subsets is made up of cells that are myeloid-restricted (STRC-Ms). These cells produce a rapid but very short-lived wave of predominantly myeloid cells (up to 4 weeks post-transplant). The second subset of STRCs are cells that have dual lymphoid and myeloid potential (STRC-MLs) but do not self-renew. As a result, their output of mature cells is also transient, albeit for a slightly longer period (up to 13 weeks post-transplant). In contrast, LTRCs repopulate NOD/SCID mice as efficiently as NOD/SCID- $\beta 2$-microglobulin null mice and have extensive self-renewal activity. However, LTRCs are much rarer than STRCs and hence their output of mature progeny in NOD/SCID- $\beta 2$-microglobulin null recipients of unseparated CD34 ${ }^{+}$ cell suspensions is initially obscured by the output of cells from the co-transplanted STRC-Ms and STRC-MLs [32,33]. The lower panel shows a diagrammatic breakdown of the output patterns expected from each of 3 types of repopulating cells expected to be present in the $\mathrm{CD}_{3}{ }^{+}$cells transplanted in the upper panel. When all 3 subsets engraft (as occurs in the NOD/SCID- $\beta 2$-microglobulin null mice), they produce a combined pattern that is the same as shown by the solid line in the upper panel. In contrast, the dotted line in both panels indicates an exclusive contribution of cells from the LTRCs which is the same in both types of host.

ed using the same procedures and endpoints as have been devised for normal hematopoietic cells. However, whereas the leukemic clone dominates all later myeloid compartments in most patients, including the uncom- mitted cells that produce colonies of erythroid, granulopoietic and megakaryocytic cells, the most primitive compartments are typically still dominated by normal cells (Fig. 1) [23,36].

\section{Phenotypic biomarkers of CML stem cells}

Flow cytometry has been used extensively to characterize functionally defined subsets of primitive normal and CML cells. These studies have shown that both share the same low forward and side light scattering characteristics indicative of a small size and agranular cytoplasm and a cell surface phenotype that includes the expression of CD34, Thy1/CD90 and AC133/CD133, and a lack of expression of CD38, CD45RA and CD71 as well as several lineage (lin) markers that characterize different types of mature blood cells. The latter include the T-cell markers: CD3, CD4 and CD8, the NK cell marker: CD56, the B-cell markers: CD19, CD 20 and CD45RA, the monocyte and granulocyte markers: CD13, CD14 and CD66b, the megakaryocyte and platelet marker: CD61, and the erythroid cell markers: CD36 and Glycophorin A [37-43]. Notably, the lin ${ }^{-} \mathrm{CD} 34^{+} \mathrm{CD}^{-} 8^{-}$fraction of $B C R-A B L^{+} / \mathrm{Ph}^{+}$cells in $\mathrm{CP} C M L$ patients contains the majority of transplantable leukemic stem cells, as defined functionally by their activity in vitro as LTC-ICs and by their sustained repopulating cell activity in vivo in immunodeficient mice. These findings mirror results accumulated for normal adult human cells with these functionally defined activities. Similarly, the phenotypically more differentiated CD $34{ }^{+} \mathrm{CD} 38^{+} \mathrm{CML}$ cells contain the majority of transplantable progenitors detectable in vivo as short term repopulating cells (STRCs) and in vitro as CFCs $[24,34,44]$.

Other phenotypic markers used to distinguish murine HSCs from closely related cells include an ability to efflux Rhodamine-123 (Rho) and Hoechst 33342 [45, 46]. In primitive hematopoietic cells, these 2 properties appear to be mediated by different members of the ATP-binding cassette (ABC) family of transporters: P-glycoprotein [47] and Abcg2/Bcrp1 [48], respectively. Detection of verapamil-inhibited fluorescence is typically used to relate lack of Rho retention to P-glycoprotein activity in primitive hematopoietic cells. Similarly, Abcg2 activity in these cells has been related to their verapamil-sensitive ability to efflux Hoechst 33342 - often visualized as the generation of a verapamil-sensitive side population (SP) in FACS profiles that depict fluorescence emissions in 2 
wave lengths [49]. However, in the mouse, it is now clear that both Rho and Hoechst 33342 efflux activities in HSCs vary with their cycling status [50], a phenomenon that extends to many other surface antigens originally thought to be characteristic of these cells in the normal adult (e.g., CD34 and CD11b/Mac1) (reviewed in [51]). Therefore many markers that are useful indicators of HSCs in normal adult mouse bone marrow are no longer applicable when these cells are perturbed. Normal adult human HSCs also show an ability to efflux Rho [52], consistent with their quiescent status, whereas, many primitive CML cells do not efflux Rho [37]. However, this may simply reflect the fact that a higher proportion of CML LTC-ICs are actively cycling [23].

The situation in the case of the SP phenotype is more complex. In the mouse, HSCs can also be seen to vary in their possession of a SP phenotype according to their cycling status, although the precise relationship between these 2 parameters has not been delineated. Indeed, it is likely that other factors play a role in controlling the possession of an SP phenotype since changes in this property may not precisely mirror changes in cycling activity. Moreover, in humans, all NOD/SCID repopulating cells in the fetal liver have an SP phenotype [53], whereas the only SP cells in adult human tissue that have any repopulating activity appear to be lymphoid restricted. [54]. Interestingly, SP cells have recently been identified in several solid tumors, including samples of neuroblastoma, breast cancer and lung cancer $[55,56]$. In the case of AML, expression of CD123 (the alpha chain of the IL-3 receptor) has been described as a reliable marker of leukemic stem cells, including CD34 ${ }^{+}$CD $38^{-}$CML cells, but not their normal counterparts [57,58].

\section{Deregulated biological properties of CML stem cells}

Thus functionally defined CML stem cells appear very similar phenotypically to their normal counterparts with certain exceptions. These exceptions can generally be related to the expression of markers that vary according to the activation or cycling status of the cells and hence may simply reflect differences in the proportion of CML stem cells that are proliferating at any given time. Evidence that primitive CML cells have a higher proportion of their members in cycle was first provided by studies that measured the sensitivity of primitive clonogenic cells to a brief ex- posure to high specific activity ${ }^{3} \mathrm{H}$-thymidine. These experiments showed that primitive normal CFCs are predominantly quiescent whereas their CML counterparts are predominantly cycling $[59,60]$. Later, evidence of an increased turnover of CML LTC-ICs was obtained by examining their distribution in different phases of the cell cycle defined using Hoechst 33342 and Pyronin Y staining [61]. The more discriminating power of these latter experiments also revealed that, at any given moment, a significant fraction of the CD34 ${ }^{+}$ leukemic cells from CP CML patients are quiescent. This quiescent population includes some members of the leukemic $\mathrm{CD} 34{ }^{+} \mathrm{CD} 38^{+}$compartment as well as many of the leukemic $\mathrm{CD} 34^{+} \mathrm{CD} 38^{-}$cells and many of the leukemic LTC-ICs [62]. Nevertheless, when these quiescent CML cells were stimulated by growth factors in single-cell suspension cultures, they rapidly entered the cell cycle and produced leukemic progeny. Entry of these cells into a proliferative mode was also demonstrated when they were placed in culture with stromal cells under conditions used to detect LTC-ICs, or when they were transplanted into sublethally irradiated NOD/SCID mice. Together these observations clearly demonstrate that the quiescent status of primitive CML cells is transient and reversible. The fact that this reversibility can be demonstrated in vivo, points to the likely importance of these cells in sustaining and spreading the disease in patients. Nevertheless, the existence of such primitive, transiently quiescent CML cells may explain the inability of chemotherapy to eradicate CML, as well as the late relapses occasionally seen many years after a transplantation procedure has been performed $[63,64]$. Indeed, primitive quiescent CML cells have now been found to also be highly resistant to IM and other BCR-ABL-targeted therapies [65, $66]$.

We have also provided evidence that CML stem cells have an intrinsically determined, reduced self-renewal ability [23,67] which is recapitulated in the leukemias that are caused by $B C R-A B L$-transduction of primitive murine HSCs [68]. This reduced self-renewal ability results in an increased rate of differentiation of CML stem cells as compared to their normal counterparts under conditions where their proliferation is stimulated. Thus, under "normal" conditions when the majority of normal HSCs are quiescent, CML stem cells depend on their increased rate of turnover to accumulate. However, when conditions that are potently mitogenic to all HSCs are induced, either in vitro or in vivo, the net growth of normal HSCs is initially greater than that achieved by CML stem cells $[23,69]$. In contrast, 
at subsequent stages of leukemic progenitor differentiation (primitive CFCs), continuation of a heightened proliferative activity gives the leukemic cells a marked advantage thus offering an explanation for the ability of the $B C R-A B L^{+}$cells to acquire clonal dominance in spite of a prevalence of normal HSCs.

Multiple mechanisms that contribute to a heightened proliferative activity of primitive CML CFCs involving both positive and negative regulators of their normal counterparts have been described. For example, we have shown that primitive CML cells are unresponsive to certain chemokines (MIP- $1 \alpha, \mathrm{MCP}-1$ and SDF-1) that inhibit the cycling of primitive normal cells [7074]. These findings have been interpreted as indicating a common pathway used by all of these chemokines to suppress proliferation in different types of primitive hematopoietic cells which the $B C R-A B L$-encoded oncoprotein can subvert or override. However, regardless of the ultimate mechanism identified, it is important to note that primitive CML cells are not resistant to all inhibitors of normal progenitor cycling activity. The turnover of both is similarly regulated by TGF$\beta[75,76]$, thus providing a possible explanation for the finding that many of the most primitive CML cells are quiescent at any given moment.

\section{Molecular biomarkers based on specific deregulated gene expression in CML stem cells}

As described above, leukemic stem cells from chronic phase CML patients have been difficult to study owing to their rarity and phenotypic overlap with normal HSCs. Most research on the effects of $B C R-A B L$ expression has therefore focused on identifying the various signal transduction pathways that are activated in $B C R-A B L^{+}$murine and human cell line model systems or in clones generated from primitive murine bone marrow cells that have been transduced with a $B C R-A B L$ CDNA and only a few studies have been able to investigate $B C R-A B L$-mediated alterations in gene expression in primary CML stem cells or their closely related derivatives. Nevertheless, understanding the molecular mechanisms of deregulated gene expression in these critical cells may well provide important clues for developing new diagnostic and therapeutic strategies, including strategies for understanding and treating disease progression. For example, a recent unexpected finding is the relative lack of responsiveness of highly enriched populations of primitive CML cells to IM and other $B C R-A B L$-targeted drugs as compared to their more differentiated progeny (Fig. 3) [36,77]. A second finding is the evidence of a heightened genomic instability in primitive CML cells of likely relevance to their accumulation of IM resistant mutations and other changes that cause the disease to progress [78-80]. Both of these findings have intensified interest in more fully delineating the properties (biomarkers) of primitive CML cells that may explain these novel features.

\subsection{Deregulated expression of $B C R-A B L$ in $C M L$ stem cells}

Three different groups have independently reported that $B C R-A B L$ expression is highly elevated in the most primitive subset of lin $^{-} \mathrm{CD} 34^{+} \mathrm{CD} 38^{-} \mathrm{CML}$ cells and is then rapidly and progressively reduced as these cells differentiate $[66,77,81]$. Interestingly, the levels of $B C R-A B L$ transcripts present in the most primitive CML stem cells are much higher than those present in the $\mathrm{G}_{0}$ fraction of CML CD34 ${ }^{+}$cells (by a factor $\sim 50$ ) [77]. In addition, the pronounced changes in $B C R-A B L$ expression seen in different subsets of chronic phase CML stem cells do not mirror the changes seen in expression of $B C R$. Expression of $B C R$, like $B C R-A B L$, decreases progressively as CML cells differentiate, but with a maximum change overall of only 10 to 15 -fold (as compared to $>100$-fold for $B C R$ $A B L)$ [77]. This disparity suggests the operation of a novel mechanism that leads to a marked increase in the levels of $B C R-A B L$ transcripts in very primitive CML cells. Investigating the basis of this deregulated expression of $B C R-A B L$, the possible role of the primitive cell context in which it occurs, and its possible generality to other fusion oncogenes will be of considerable interest in future studies.

The observed changes in $B C R-A B L$ transcript levels also result in changes in $\mathrm{p} 210^{B C R-A B L}$ oncoprotein expression and activity, although these appear to be less pronounced [77]. Since CRKL is a major target of p210 ${ }^{B C R}-A B L$ kinase activity [82-84], it would then be expected that the levels of phosphorylated CRKL in the most primitive CML cells would also be highest, as is, in fact observed [77]. Subsequent studies in $B C R-A B L^{+}$cell line models have provided definitive evidence that the level of $B C R-A B L$ expression alone can be a determinant of IM responsiveness $[77,85]$.

\subsection{Activated autocrine mechanism in CML stem cells}

One of the earliest findings from studies of $B C R$ $A B L$-transduced hematopoietic cell lines was the acti- 

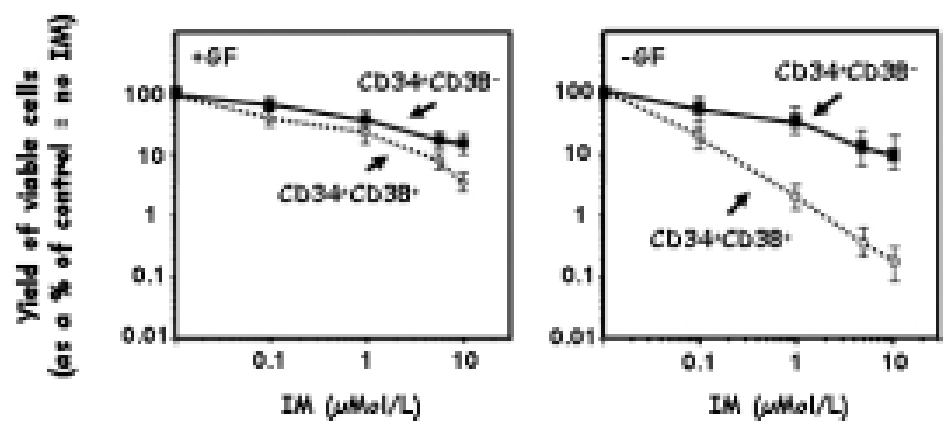

Fig. 3. Intrinsically determined lack of responsiveness of CML-stem cell enriched populations to IM. The graphs show a comparison of the differential recovery of viable cells from suspension cultures initiated with purified CD34 $\mathrm{CD}^{-} 8^{-}$(solid lines) and CD34 ${ }^{+} \mathrm{CD} 38^{+}$(dotted lines) CML cells and then incubated for 3 weeks in the presence of varying concentrations IM, either in the presence (left panel) or absence (right panel) of growth factors. Under either condition, the leukemic CD38- subset is more resistant than the $\mathrm{CD}^{-} 8^{+}$subset to IM (relative reduction in viable cells recovered due to IM is less). Moreover, this differential is enhanced when cell survival and proliferation is forced to depend on the autocrine mechanisms possessed by both sets of primitive leukemic cells used to initiate the cultures. Data is taken from Ref 77 . GF $=$ growth factors.

vation of an autocrine mechanism which could confer partial or complete growth factor autonomy in cells that were previously factor-dependent $[86,87]$. However, for many years, this finding was considered a cell line anomaly because a similar abnormality was not evident in studies of primary CML cells. Then, when it became feasible to look for alterations in gene expression in small numbers of cells, we discovered that most CD34 ${ }^{+}$CML cells display a constitutively activated production of IL-3 and granulocyte-colony stimulating factor (G-CSF) [67]. This gives these cells the expected factor-independent phenotype and accounts for their increased levels of phosphorylated STAT5. Consistent with these latter observations was the finding that the autocrine production of IL-3 and G-CSF in primitive CML cells is silenced when they become quiescent, and is then reversed when they begin to proliferate [62]. Activation of this autocrine mechanism appears to be an intrinsically determined property of $B C R-A B L^{+} / \mathrm{Ph}^{+}$ cells, since it reappears in the $\mathrm{CD} 34^{+}$progeny of $\mathrm{CML}$ cells that are regenerated in transplanted sheep [88] and mice, and is rapidly induced when primitive normal human [89] or murine [90-93] hematopoietic cells are transduced with $B C R-A B L$.

The combination of an increased turnover and decreased self-renewal ability of primitive CML cells has been recognized for many years, as noted above [23]. However, a molecular mechanism that might account for this duality has remained elusive. The simultaneous discovery that very primitive normal hematopoietic cells exposed to excessive concentrations of IL-3 and G-CSF in vitro show an intense proliferative response that is coupled to diminished self-renewal activity was therefore of great interest [94]. Accordingly, we spec- ulated that the self-stimulation of primitive CML cells by autocrine IL-3/G-CSF contributes to both of these abnormal features of their biology. Similarly, at later stages of normal $\mathrm{CD} 34^{+}$cell differentiation, the same 2 growth factors would be expected to simply promote cell survival and proliferation. It would thus be anticipated that an autocrine IL-3/G-CSF loop active in $\mathrm{CD} 34{ }^{+} \mathrm{CD} 38{ }^{+} \mathrm{CML}$ cells might, likewise, contribute to their competitive expansion potential.

Quantification of the levels of IL-3 and G-CSF transcripts in different subsets of CML cells has shown that these are both highest in CML stem cells and then progressively decrease together, even before the cells leave the $\mathrm{CD} 34{ }^{+} \mathrm{CD} 38^{+}$compartment [77]. Thus during the differentiation of primitive CML cells, the level of expression of $B C R-A B L$ correlates with the expression of IL-3 and G-CSF. This observation is of some practical relevance given the reduced IM sensitivity displayed by $\operatorname{lin}^{-} \mathrm{CD} 34^{+} \mathrm{CD} 38^{-} \mathrm{CML}$ cells, as compared with the lin $^{-} \mathrm{CD} 34^{+} \mathrm{CD} 38^{+}$cells in vitro in the absence of exogenously provided growth factors. Recently, it was found that in vitro pulsing of initially quiescent CML progenitors with G-CSF prior to and following treatment with IM promotes the re-entry of these IM-insensitive cells into the cell cycle and their significantly enhanced elimination as compared to IM treatment alone [95]. Autocrine production of GMCSF in CML cells has also recently been reported together with evidence suggesting that this mechanism may contribute to IM and nilotinib-resistance in $B C R$ $A B L^{+}$progenitors through activation of the JAK/STAT pathway [96]. Taken together, the autocrine production of cytokines in primitive CML cells is likely to be a multifaceted, but important mechanism contributing to 
responses to $B C R$ - $A B L$-targeted therapies and itself a potential additional therapeutic target.

\subsection{Deregulated expression of $A B C$ transporters in CML stem cells}

Many members of the ABC transporter superfamily promote the uptake or efflux of specific drugs and can therefore be clinically important determinants of intracellular drug concentrations achievable in vivo or in vitro [97]. One particularly intriguing property of stem cells is that they express high levels of 2 particular ABC transporters. One of these is ABCB1 (also called P-glycoprotein) and the other is ABCG2 (also called breast cancer resistance protein, or BCRP) $[48,98,99]$. IM is a substrate of ABCB1 and overexpression of the $A B C B 1$ gene has been implicated as a cause of IM resistance in CML [100-105]. However, this finding has not been universally supported [106,107]. In cell lines engineered to overexpress $A B C G 2$, IM has been found to interact with the protein product [108-111] by competitive attachment of IM to the ATP-binding site on ABCG2. Thus, IM is not a substrate of ABCG2 and ABCG2 does not efflux IM. Rather, IM is an inhibitor of ABCG2 activity.

In primitive $\mathrm{CML}$ cells isolated directly from chronic phase CML patients, $A B C G 2$, like $A B C B 1$, is overexpressed relative to the same subsets of primitive normal cells (Fig. 4) [77,112]. However, mice deficient in either $A b c b 1$ or $A b c g 2$ are viable, fertile and have normal HSC compartments [113,114]. This indicates that none of these genes are individually required for normal HSC growth or maintenance, although mice lacking these genes do show increased sensitivity to the lethal effects of drugs such as vinblastine, ivermectin and mitoxantrone, consistent with a role of these $\mathrm{ABC}$ transporters in protecting cells from toxins.

OCT-1, another transporter, appears to be a major regulator of IM uptake [115,116]. Interestingly, lower OCT1 transcript levels have been reported in IM nonresponders by comparison to IM responders in a study cohort of $30 \mathrm{CML}$ patients [117]. In addition, it has been found that primary CML cells with lower than average OCT1 activity display reduced sensitivity to IM in vitro. The combination of low expression of OCT1 and elevated expression of $A B C B 1$ and $A B C G 2$ might thus be expected to contribute to a poor therapeutic response. We have found that this transporter phenotype is exactly what is seen in the most primitive CP CML cells by comparison both to their normal counterparts and to their more differentiated progeny (Fig. 4) [77].
Conversely, transcript levels for $A B C B 1$ and $A B C G 2$ are highest in the normal HSC-enriched subset and lowest in the most mature normal cells and this difference is further exaggerated in the corresponding subsets of CML cells. Taken together, these findings indicate a variety of perturbations that likely contribute to the relative IM resistance of the most primitive CML cells.

\subsection{Deregulated expression of AHI-1 in CML stem cells}

Another gene that may cooperate with $B C R-A B L$ at the stem cell level is a novel oncogene, AHI-1, (Abelson helper integration site-1) [118]. Ahi-1, the murine gene, was originally discovered by analysis of the site of proviral insertions in various v-abl and myc-induced murine leukemias and lymphomas [119-124]. Subsequent demonstration of a high frequency of Ahi-1 mutations in certain virus-induced murine leukemias provided more direct evidence that Ahi-l has leukemogenic activity [118]. This gene encodes a modular protein with a SH3 domain, SH3 binding domains, and multiple WD-repeat domains, suggesting novel signaling activities. Interestingly, the conserved homologous human gene (AHI- 1 ) encodes an additional coiled-coil domain in the $\mathrm{N}$-terminal region of the protein which is entirely missing from the mouse Ahi-1 protein.

Ahi-1/AHI- 1 is normally expressed in the most primitive murine and human hematopoietic cells and then shows similar specific patterns of downregulation in different lineages [125]. Thus downregulation of AHI1 expression appears to be an important conserved step in the normal regulation of early hematopoietic cell differentiation. Interestingly, $A H I-1$ transcripts levels are abnormally elevated in K562 cells, a line derived from a CML patient in blast crisis, and also in primary CML cells from patients at all stages of their disease, but not in many types of patients with $\mathrm{Ph}^{-}$leukemias. Moreover, in CML, the highest levels of $A H I-1$ transcripts are found in the leukemic stem cells. Thus, there is a similar pattern of upregulated $B C R-A B L$ and $A H I-1$ expression in primitive CML cells. This may, in fact, be important to the loss of stem cell self-renewal capacity and accelerated activation of differentiation programs that is characteristic of CP CML cells. Accordingly, mechanisms that impede the normal downregulation of expression of $A H I-1$ in primitive hematopoietic cells, or that inappropriately stimulate its expression in immediate cells, might be predicated to have leukemogenic sequelae. Indeed, we have recently found that overexpression of Ahi-1 alone in primitive murine 

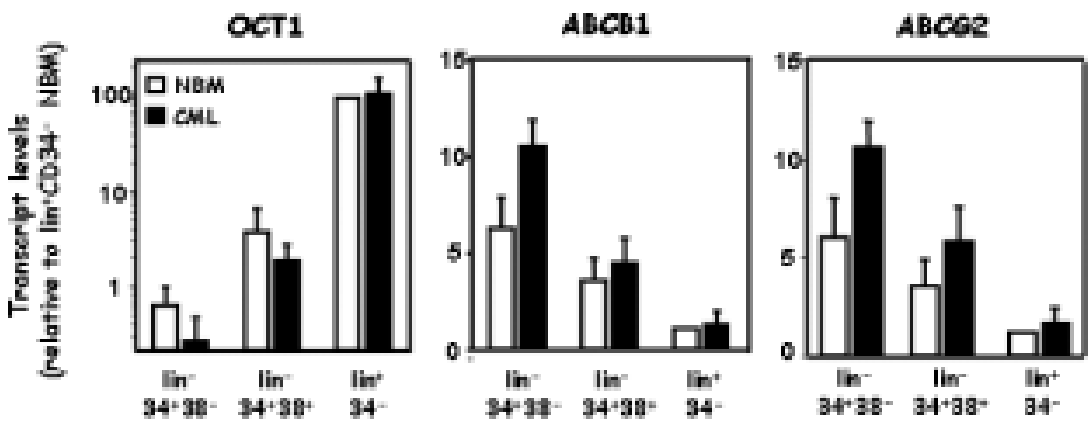

Fig. 4. Altered expression of certain transporter genes in primitive CML cells. The reduced expression of $O C T 1$ and the increased expression of $A B C B 1$ and $A B C G 2$ in primitive normal human bone marrow (NBM) cells is exaggerated in their CML counterparts, as shown by quantitative real-time PCR measurements of the RNAs present in extracts of the purified cell fractions indicated (lin $\mathrm{CD}^{-} 4^{+} \mathrm{CD}^{-} 8^{-}=$stem cell enriched, $\operatorname{lin}^{-} \mathrm{CD} 34^{+} \mathrm{CD}_{3} 8^{+}=$intermediate progenitors, lin ${ }^{+} \mathrm{CD} 34^{-}=$terminally differentiating cells). These findings suggest that the most primitive CML cells express reduced levels of the transporter required to bring IM into the cell, and increased levels of transporters that can export and/or bind IM. Data is taken from Ref 77.

hematopoietic cells confers on them a proliferative advantage in vitro and a lethal leukemogenic activity in vivo. Moreover, both of these effects are enhanced by co-transduction of the cells with $B C R-A B L$ [126]. Taken together, these findings suggest a potential role of $A H I-1$ in mediating or enhancing the transforming activity of $B C R-A B L$ in CML cells and possibly in contributing to the subsequent progression of the disease to a more acute form.

\subsection{Global gene expression analyses of chronic phase CML stem cells}

Kronenwett $\mathrm{R}$ and co-workers reported the first comparison of the total transcriptome of CD34 ${ }^{+}$CML cells with their normal counterparts from adult bone marrow and mobilized peripheral blood using both cDNA arrays and oligonucleotide arrays [127,128]. Evidence of activation of the MAPK, PI3K/AKT, JAK/STAT, MYC and RAS pathways in the primitive CML cells were detected as predicted. These studies also demonstrated that the expression of several genes involved in DNA repair, including $R A D 23 A, E R C C 1, E R C C 3$ and $E R C C 5$, was significantly reduced (2 to 4-fold) in the CML cells supporting the concept that the DNA repair machinery in CML cells is abnormal $[129,130]$. Abnormal adhesion and homing are additional reported features of primitive CML cells [131-134], and it is therefore interesting that $N$-CADHERIN, L-SELECTIN, $C X C R 4$ and $C C R 2$ transcripts were also found to be downregulated in $\mathrm{CD} 34^{+} \mathrm{CML}$ cells as compared to their normal counterparts. Another gene implicated in CML and that showed altered ( $\sim 5$-fold lower) expression in these studies was IRF8 (ICSBP1). The biological importance of reduced $I R F 8$ expression in the pathogenesis of CML has been suggested by studies showing that Irf8 deletion in mice causes the development of a CML-like myeloproliferative syndrome [135] and forced expression of Irf8 inhibits the growth of $B C R-A B L$-transformed primary murine bone marrow cells [136]. Conversely, transcripts for the leptin receptor (LEPR), SKI (a transcriptional co-repressor) and the adenosine A receptor (a neurobiological receptor gene also expressed in G-CSF-mobilized normal blood progenitors [137]) were increased in CML cells. In this regard, it is interesting that treatment of CML cells in vitro with DPCPX, an antagonist of the adenosine A1 receptor, suppressed the formation of erythroid and granulopoietic colonies by CML progenitors more than by normal bone marrow progenitors. Finally, evidence of activation of the proteasome-ubiquitin protein pathway in primitive CML cells was also evident from the same gene expression comparisons also consistent with biological evidence of a selective effect of proteasome inhibitors on CML progenitors [138,139].

Although the $B C R-A B L$ gene is believed to be both necessary and sufficient to initiate the development of CP CML, it is not known whether changes in other genes not evident at a cytogenetic level may also commonly contribute to this process. Thus, differentially expressed genes revealed by previous studies might not necessarily be deregulated as a direct result of expression $\mathrm{p} 210^{\mathrm{BCR}-\mathrm{ABL}}$, but reflect additionally acquired mutations or epigenetic abnormalities. To identify genes whose expression in primitive human hematopoietic cells are directly upregulated by expression of $B C R-A B L$, Verfaillie's group prepared a cDNA library from extracts of $B C R-A B L$-transduced cells from which cDNAs present in control human $\mathrm{CD} 34^{+}$ cord blood cells had been subtracted [140]. About half 
of the several dozen clones thus identified were homologous to known genes. One of these was NUP98, which has been implicated in many translocations associated with the development of AML [141]. Others appeared to encode novel proteins. Although some of these findings were confirmed by gene expression analysis of primary CML cells, not all of the changes identified were reversed by IM treatment.

Transcriptome profiling has also been used to try to identify biomarkers of IM responsiveness. Such studies have identified genes associated with $\mathrm{NF} \kappa \mathrm{B}$ activation, cell adhesion [142], DNA damage repair, oxidative stress responses [143] and drug metabolism [144]. One study attempted to generate a risk assessment method based on the application of a subset of genes selected from initial array data to a test group of 12 IMtreated patients (10 responders and 2 nonresponders). The results assigned all of the responders and one of the nonresponders to the low-risk group, with the other nonresponder being assigned to the intermediate-risk group. These data suggested that clinical responses to IM treatment might be predictable by certain gene expression parameters.

\subsection{Indicators of disease progression}

The onset of disease progression from CP to blast crisis is well known to be highly variable if cytogenetic remissions are not achieved, in spite of the absence of other mutations detectable by standard cytogenetics. The classic view has been that the progression of CML is caused by the acquisition of a rare second event. Such events have been thought to occur stochastically, but at a higher rate within the $\mathrm{CP}$ clone than in their normal counterparts due to the greater proliferative activity of the primitive CML cells in concert with their genomic instability [36]. Predicting such changes is clearly of considerable clinical importance in selecting an optimal therapeutic option since the presence of even undetectable levels of blast phase disease is likely to prevent durable remissions from being achieved unless myeloablative chemotherapy and a stem cell transplant is given. An interesting attempt to address this question was recently reported by Yong et al. [145]. They first compared the CD34 ${ }^{+}$leukemic cells from $3 \mathrm{CP}$ patients who progressed to blast crisis within 3 years of diagnosis and 10 whose blastic transformation took place more than 7 years after diagnosis. This comparison revealed 20 genes whose expression was significantly different between the 2 groups and this difference was confirmed by quantitative reverse transcrip- tase PCR measurements for 18 of these. Application of a multivariate Cox regression model to a complete cohort of 68 patients then showed an association of 2 of these with more prolonged survival; i.e., a low expression of $\mathrm{CD} 7$ in combination with a high expression of either proteinase 3 or elastase.

\section{Future directions}

Accumulated knowledge of the unique biological properties of CP CML stem cells underscores the need for more comprehensive information about their molecular alterations. This is crucial to allow newer therapies to be devised and deployed with greater predictive power of the risk-benefit for individual patients. We anticipate that much of this anticipated progress will come from large scale comparisons of the genome, transcriptome and proteome of more highly purified populations of normal and CML stem cell populations. However, such studies will also need to be accompanied by technical improvements for performing such studies with adequate depth and fidelity on the very small numbers of cells that can realistically be isolated from an individual sample $\left(<10^{3}\right)$. As a first step towards this goal, we have recently developed a modified Serial Analysis of Gene Expression (SAGE) protocol based on the PCR-LongSAGE method [146]. This innovation allows global transcriptome profiling to be usefully applied to as few as $10^{3}$ primary hematopoietic cells. As a first proof-of-principle experiment, we further showed how this methodology could be used to identify novel transcripts in a 200,000 tag LongSAGE library prepared from extracts of FACS-purified lin ${ }^{-} \mathrm{CD} 34^{+}$normal human adult bone marrow cells [146]. More recently, we have constructed and sequenced similar libraries from the $\mathrm{CD}_{3} 8^{+}$and $\mathrm{CD}^{-} 8^{-}$subsets of the CD34 ${ }^{+}$CML population from several CP patients and their phenotypic counterparts in normal adult human hematopoietic tissues. We anticipate that the results of comparative analyses of these datasets and additional meta-comparisons with published transcriptome data will provide important new clues about key molecular properties of CML stem cells.

\section{Conclusion}

The discovery of IM has revolutionized the treatment of CML. While the vast majority of early CP patients continue to do well with an excellent quality of life, 
there is a smaller cohort of patients that are not well served by treatment with this agent. It is these patients along with more advanced phase patients that require alternative therapeutic options. To date, the most sensitive method for assessing the effectiveness of IM therapy is to monitor peripheral blood $B C R-A B L$ transcript levels using real-time PCR. This strategy can usually forecast the emergent expansion of resistant subclones but is not able to detect the original presence of the mutant or progressed CML stem cells from which such subclones are presumed to arise. Here we describe a number of properties of CP CML stem cells that distinguish them from normal HSCs and from the bulk of the CML clone which is comprised of leukemic cells that have begun to differentiate into various mature blood cell types. Some of these features of CML stem cells can already account for their abnormal growth characteristics, their innate insensitivity to $B C R-A B L-$ targeted agents (as well as conventional chemotherapeutic drugs), and their tendency to generate mutant derivatives. New approaches for investigating CML stem cell features and their diversity in individual patients should greatly facilitate the goal of predicting individual patient responses and the development of more effective therapies for those not optimally served by current regimens that rely on single $B C R$ - $A B L$-targeted agents.

\section{Acknowledgements}

This work was supported in part by grants from the Cancer Research Society and the Leukemia \& Lymphoma Society of Canada (to X.J.) and from the National Cancer Institute of Canada (with funds from the Canadian Cancer Society and the Terry Fox Foundation to A.E., X.J. and C.E.). X. Jiang and C. Smith are Michael Smith Foundation for Health Research Scholars. Y. Zhao was a recipient of a Stem Cell Network Fellowship and a Leukemia \& Lymphoma Society of Canada Fellowship.

\section{References}

[1] M. Sattler and J.D. Griffin, Molecular mechanisms of transformation by the BCR-ABL oncogene, Semin Hematol 40 (2003), 4-10

[2] J.V. Melo and M.W. Deininger, Biology of chronic myelogenous leukemia - signaling pathways of initiation and transformation, Hematol Oncol Clin North Am 18 (2004), 545568 .
[3] T.G. Lugo, A.M. Pendergast, A.J. Muller and O.N. Witte, Tyrosine kinase activity and transformation potency of $\mathrm{bcr}$ abl oncogene products, Science 247 (1990), 1079-1082.

[4] G.Q. Daley, R.A. Van Etten and D. Baltimore, Induction of chronic myelogenous leukemia in mice by the $\mathrm{P} 210^{\mathrm{bcr} / \mathrm{abl}}$ gene of the Philadelphia chromosome, Science 247 (1990), 824-830.

[5] B.J. Druker, S. Tamura, E. Buchdunger, S. Ohno, G.M. Segal, S. Fanning, J. Zimmermann and N.B. Lydon, Effects of a selective inhibitor of the Abl tyrosine kinase on the growth of Bcr-Abl positive cells, Nat Med 2 (1996), 561-566.

[6] B.J. Druker, M. Talpaz, D.J. Resta, B. Peng, E. Buchdunger, J.M. Ford, N.B. Lydon, H. Kantarjian, R. Capdeville, S. Ohno-Jones and C.L. Sawyers, Efficacy and safety of a specific inhibitor of the BCR-ABL tyrosine kinase in chronic myeloid leukemia, N Engl J Med 344 (2001), 1031-1037.

[7] H. Kantarjian, C. Sawyers, A. Hochhaus, F. Guilhot, C. Schiffer, C. Gambacorti-Passerini, D. Niederwieser, D. Resta, R. Capdeville, U. Zoellner, M. Talpaz, B. Druker, J. Goldman, S.G. O'Brien, N. Russell, T. Fischer, O. Ottmann, P. ConyMakhoul, T. Facon, R. Stone, C. Miller, M. Tallman, R. Brown, M. Schuster, T. Loughran, A. Gratwohl, F. Mandelli, G. Saglio, M. Lazzarino, D. Russo, M. Baccarani and E. Morra, Hematologic and cytogenetic responses to imatinib mesylate in chronic myelogenous leukemia, $N$ Engl $\mathrm{J} \mathrm{Med}$ 346 (2002), 645-652.

[8] H. Kantarjian, F. Giles, L. Wunderle, K. Bhalla, S. O'Brien, B. Wassmann, C. Tanaka, P. Manley, P. Rae, W. Mietlowski, K. Bochinski, A. Hochhaus, J.D. Griffin, D. Hoelzer, M. Albitar, M. Dugan, J. Cortes, L. Alland, and O.G. Ottmann, Nilotinib in imatinib-resistant CML and Philadelphia chromosome-positive ALL, N Engl J Med 354 (2006), 2542-2551.

[9] M. Talpaz, N. P. Shah, H. Kantarjian, N. Donato, J. Nicoll, R. Paquette, J. Cortes, S. O'Brien, C. Nicaise, E. Bleickardt, M.A. Blackwood-Chirchir, V. Iyer, T.T. Chen, F. Huang, A.P. Decillis and C.L. Sawyers, Dasatinib in imatinib-resistant Philadelphia chromosome-positive leukemias, $N$ Engl J Med 354 (2006), 2531-2541.

[10] B.J. Druker, F. Guilhot, S.G. O'Brien, I. Gathmann, H. Kantarjian, N. Gattermann, M.W. Deininger, R.T. Silver, J.M. Goldman, R.M. Stone, F. Cervantes, A. Hochhaus, B.L. Powell, J.L. Gabrilove, P. Rousselot, J. Reiffers, J.J. Cornelissen, T. Hughes, H. Agis, T. Fischer, G. Verhoef, J. Shepherd, G. Saglio, A. Gratwohl, J.L. Nielsen, J.P. Radich, B. Simonsson, K. Taylor, M. Baccarani, C. So, L. Letvak and R.A. Larson, Five-year follow-up of patients receiving imatinib for chronic myeloid leukemia, N Engl J Med 355 (2006), 2408-2417.

[11] A. Hochhaus and P. La Rosee, Imatinib therapy in chronic myelogenous leukemia: strategies to avoid and overcome resistance, Leukemia 18 (2004), 1321-1331.

[12] T. Lahaye, B. Riehm, U. Berger, P. Paschka, M. C. Muller, S. Kreil, K. Merx, U. Schwindel, C. Schoch, R. Hehlmann and A. Hochhaus, Response and resistance in 300 patients with BCR-ABL-positive leukemias treated with imatinib in a single center: a 4. 5-year follow-up, Cancer 103 (2005), 1659-1669.

[13] H.M. Kantarjian, M. Talpaz, S. O’Brien, F. Giles, G. GarciaManero, S. Faderl, D. Thomas, J. Shan, M.B. Rios and J. Cortes, Dose escalation of imatinib mesylate can overcome resistance to standard-dose therapy in patients with chronic myelogenous leukemia, Blood 101 (2003), 473-475.

[14] E. Jabbour, H. Kantarjian, S. O'Brien, M.B. Rios, L. Abruzzo, S. Verstovsek, G. Garcia-Manero and J. Cortes, Sud- 
den blastic transformation in patients with chronic myeloid leukemia treated with imatinib mesylate, Blood 107 (2006), 480-482.

[15] H. Kantarjian, S. O'Brien, J. Cortes, F. Giles, D. Thomas, S. Kornblau, J. Shan, R. M. Beth, M. Keating, E. Freireich and M. Talpaz, Sudden onset of the blastic phase of chronic myelogenous leukemia: patterns and implications, Cancer 98 (2003), 81-85.

[16] A. Gratwohl, R. Brand, J. Apperley, C. Crawley, T. Ruutu, P. Corradini, E. Carreras, A. Devergie, C. Guglielmi, H.J. Kolb and D. Niederwieser, Allogeneic hematopoietic stem cell transplantation for chronic myeloid leukemia in Europe 2006: transplant activity, long-term data and current results. An analysis by the Chronic Leukemia Working Party of the European Group for Blood and Marrow Transplantation (EBMT), Haematologica 91 (2006), 513-521.

[17] J.E. Sokal, E.B. Cox, M. Baccarani, S. Tura, G.A. Gomez, J.E. Robertson, C.Y. Tso, T.J. Braun, B.D. Clarkson, F. Cervantes, C. Rozman and the Italian Cooperative CML Study Group, Prognostic discrimination in "good-risk" chronic granulocytic leukemia, Blood 63 (1984), 789-799.

[18] M.E. O’Dwyer, M.J. Mauro, G. Kurilik, M. Mori, S. Balleisen, S. Olson, E. Magenis, R. Capdeville and B.J. Druker, The impact of clonal evolution on response to imatinib mesylate (STI571) in accelerated phase CML, Blood 100 (2002), 1628-1633.

[19] J.E. Cortes, M. Talpaz, F. Giles, S. O’Brien, M.B. Rios, J. Shan, G. Garcia-Manero, S. Faderl, D.A. Thomas, W. Wierda, A. Ferrajoli, S. Jeha and H.M. Kantarjian, Prognostic significance of cytogenetic clonal evolution in patients with chronic myelogenous leukemia on imatinib mesylate therapy, Blood 101 (2003), 3794-3800.

[20] B.J. Huntly, A. Bench and A.R. Green, Double jeopardy from a single translocation: deletions of the derivative chromosome 9 in chronic myeloid leukemia, Blood 102 (2003), 1160-1168.

[21] B.J. Huntly, F. Guilhot, A.G. Reid, G. Vassiliou, E. Hennig, C. Franke, J. Byrne, A. Brizard, D. Niederwieser, J. FreemanEdward, G. Cuthbert, N. Bown, R.E. Clark, E.P. Nacheva, A.R. Green and M.W. Deininger, Imatinib improves but may not fully reverse the poor prognosis of patients with CML with derivative chromosome 9 deletions, Blood 102 (2003), 2205-2212.

[22] A. Quintas-Cardama, H. Kantarjian, M. Talpaz, S. O’Brien, G. Garcia-Manero, S. Verstovsek, M.B. Rios, K. Hayes, A. Glassman, B.N. Bekele, X. Zhou and J. Cortes, Imatinib mesylate therapy may overcome the poor prognostic significance of deletions of derivative chromosome 9 in patients with chronic myelogenous leukemia, Blood 105 (2005), 2281-2286.

[23] C.J. Eaves and A.C. Eaves, Progenitor cell dynamics, in: Chronic Myeloid Leukemia: Biology \& Treatment, A.M. Carella, G.Q. Daley, C.J. Eaves, J.M. Goldman and R. Hehlmann, eds, Martin Dunitz, 2001, pp. 73-100.

[24] T.L. Holyoake, X. Jiang, M.W. Drummond, A.C. Eaves and C.J. Eaves, Elucidating critical mechanisms of deregulated stem cell turnover in the chronic phase of chronic myeloid leukemia, Leukemia 16 (2002), 549-558.

[25] S.H. Orkin and L.I. Zon, Hematopoiesis and stem cells: plasticity versus developmental heterogeneity, Nat Immunol 3 (2002), 323-328.

[26] S.H. Orkin, Diversification of haematopoietic stem cells to specific lineages, Nat Genet 1 (2000), 57-64.
[27] I.L. Weissman, Stem cells: units of development, units of regeneration and units in evolution [In Process Citation], Cell 100 (2000), 157-168.

[28] I.L. Weissman, D.J. Anderson and F. Gage, Stem and progenitor cells: origins, phenotypes, lineage commitments and transdifferentiations, Annu Rev Cell Dev Biol 17 (2001), 387403.

[29] C.J. Eaves, Myelopoiesis, in: Leukemia, E.S. Henderson, T.A. Lister and M.F. Greaves, eds, WB Saunders, 2002, pp. 19-45.

[30] E. Conneally, J. Cashman, A. Petzer and C. Eaves, Expansion in vitro of transplantable human cord blood stem cells demonstrated using a quantitative assay of their lymphomyeloid repopulating activity in nonobese diabetic-scid/scid mice, Proceedings of the National Academy of Sciences USA 94 (1997), 9836-9841.

[31] M. Bhatia, D. Bonnet, U. Kapp, J.C.Y. Wang, B. Murdoch and J.E. Dick, Quantitative analysis reveals expansion of human hematopoietic repopulating cells after short-term $e x$ vivo culture, J Exp Med 186 (1997), 619-624.

[32] H. Glimm, W. Eisterer, K. Lee, J. Cashman, T.L. Holyoake, F. Nicolini, L.D. Shultz, C. von Kalle and C.J. Eaves, Previously undetected human hematopoietic cell populations with shortterm repopulating activity selectively engraft NOD/SCID- $\beta_{2}$ microglobulin-null mice, J Clin Invest 107 (2001), 199-206.

[33] C.J. Hogan, E.J. Shpall and G. Keller, Differential long-term and multilineage engraftment potential from subfractions of human CD34+ cord blood cells transplanted into NOD/SCID mice, Proceedings of the National Academy of Sciences USA 99 (2002), 413-418.

[34] J.C.Y. Wang, C. Dorrell, C.Y. Ito, T. Inamitsu, G. Guenechea, O.I. Gan and J.E. Dick, Normal and leukemic human stem cells assayed in immune-deficient mice, in: Hematopoiesis: A Developmental Approach, L.I. Zon, ed., Oxford University Press, 2001, pp. 99-118.

[35] B. Dykstra, J. Ramunas, D. Kent, L. McCaffrey, E. Szumsky, L. Kelly, K. Farn, A. Blaylock, C. Eaves and E. Jervis, Highresolution video monitoring of hematopoietic stem cells cultured in single-cell arrays identifies new features of selfrenewal, Proceedings of the National Academy of Sciences USA 103 (2006), 8185-8190.

[36] X. Jiang, C. Smith, A. Eaves and C. Eaves, The challenges of targeting chronic myeloid leukemia stem cells, Clin Lymph Myeloma 7 (2007), S71-S80.

[37] C. Udomsakdi, C.J. Eaves, P.M. Lansdorp and A.C. Eaves, Phenotypic heterogeneity of primitive leukemic hematopoietic cells in patients with chronic myeloid leukemia, Blood 80 (1992), 2522-2530.

[38] A.L. Petzer, C.J. Eaves, P.M. Lansdorp, L. Ponchio, M.J. Barnett and A.C. Eaves, Characterization of primitive subpopulations of normal and leukemic cells present in the blood of patients with newly diagnosed as well as established chronic myeloid leukemia, Blood 88 (1996), 2162-2171.

[39] M. Bhatia, J.C.Y. Wang, U. Kapp, D. Bonnet and J.E. Dick, Purification of primitive human hematopoietic cells capable of repopulating immune-deficient mice, Proceedings of the National Academy of Sciences USA 94 (1997), 5320-5325.

[40] C.I. Civin, G. Almeida-Porada, M.-J. Lee, J. Olweus, L.W.M.M. Terstappen and E.D. Zanjani, Sustained, retransplantable, multilineage engraftment of highly purified adult human bone marrow stem cells in vivo, Blood 88 (1996), 4102-4109.

[41] T.C. Kerre, G. De Smet, M. De Smedt, F. Offner, J. De Bosscher, J. Plum and B. Vandekerckhove, Both CD $34^{+} 38^{+}$ 
and $\mathrm{CD}_{3}{ }^{+} 38^{-}$cells home specifically to the bone marrow of NOD/LtSZ scid/scid mice but show different kinetics in expansion, J Immunol 167 (2001), 3692-3698.

[42] Y. Yu, A. Flint, E.L. Dvorin and J. Bischoff, AC133-2, a novel isoform of human AC133 stem cell antigen, J Biol Chem 277 (2002), 20711-20716.

[43] A. Schulenburg, H. Ulrich-Pur, D. Thurnher, B. Erovic, S. Florian, W.R. Sperr, P. Kalhs, B. Marian, F. Wrba, C.C. Zielinski and P. Valent, Neoplastic stem cells: a novel therapeutic target in clinical oncology, Cancer 107 (2006), 25122520 .

[44] W. Eisterer, X. Jiang, O. Christ, H. Glimm, K. Lee, E. Pang, K. Lambie, G. Shaw, T.L. Holyoake, A.L. Petzer, C. Auewarakul, M.J. Barnett, C.J. Eaves and A.C. Eaves, Different subsets of primary chronic myeloid leukemia stem cells engraft immunodeficient mice and produce a model of the human disease, Leukemia 19 (2005), 435-441.

[45] I. Bertoncello, G.S. Hodgson and T.R. Bradley, Multiparameter analysis of transplantable hemopoietic stem cells: I. The separation and enrichment of stem cells homing to marrow and spleen on the basis of Rhodamine-123 fluorescence, Exp Hematol 13 (1985), 999-1006.

[46] N.S. Wolf, A. Kone, G.V. Priestley and S.H. Bartelmez, In vivo and in vitro characterization of long-term repopulating primitive hematopoietic cells isolated by sequential Hoechst 33342-rhodamine123 FACS selection, Exp Hematol 21 (1993), 614-622.

[47] M.M. Gottesman, T. Fojo and S.E. Bates, Multidrug resistance in cancer: role of ATP-dependent transporters, Nat Rev Cancer 2 (2002), 48-58.

[48] S. Zhou, J.D. Scheutz, K.D. Bunting, A.-M. Colapietro, J. Sampath, J.J. Morris, I. Lagutina, G.C. Grosveld, M. Osawa, H. Nakauchi and B.P. Sorrentino, The ABC transporter Bcrp1/ABCG2 is expressed in a wide variety of stem cells and is a molecular determinant of the side-population phenotype, Nat Med 7 (2001), 1028-1034.

[49] M.A. Goodell, K. Brose, G. Paradis, A.S. Conner and R.C. Mulligan, Isolation and functional properties of murine hematopoietic stem cells that are replicating in vivo, J Exp Med 183 (1996), 1797-1806.

[50] N. Uchida, B. Dykstra, K. Lyons, F. Leung, M. Kristiansen and $\mathrm{C}$. Eaves, $\mathrm{ABC}$ transporter activities of murine hematopoietic stem cells vary according to their developmental and activation status, Blood 103 (2004), 4487-4495.

[51] C.J. Eaves and A.C. Eaves, Part II. Cell biology and pathobiology. Anatomy and physiology of hematopoiesis, in: Childhood Leukemias, C.-H. Pui, ed., Cambridge University Press, 2006, pp. 69-105.

[52] J.L. Mckenzie, K. Takenaka, O.I. Gan, M. Doedens and J.E. Dick, Low rhodamine 123 retention identifies long-term human hematopoietic stem cells within the Lin-CD34+, Blood 109 (2007), 543-545.

[53] N. Uchida, T. Fujisaki, A.C. Eaves and C.J. Eaves, Transplantable hematopoietic stem cells in human fetal liver have a CD34 ${ }^{+}$side population (SP) phenotype, J Clin Invest 108 (2001), 1071-1077.

[54] M. Fischer, M. Schmidt, S. Klingenberg, C.J. Eaves, C. von Kalle and H. Glimm, Short term repopulating cells with myeloid potential in human mobilized peripheral blood do not have a side population (SP) phenotype, Blood 108 (2006), 2121-2123.

[55] M. Dean, T. Fojo and S. Bates, Tumour stem cells and drug resistance, Nat Rev Cancer 5 (2005), 275-284.
[56] C. Hirschmann-Jax, A.E. Foster, G.G. Wulf, J.G. Nuchtern, T.W. Jax, U. Gobel, M.A. Goodell and M.K. Brenner, A distinct "side population" of cells with high drug efflux capacity in human tumor cells, Proc Natl Acad Sci USA 101 (2004), $14228-14233$.

[57] C.T. Jordan, D. Upchurch, S.J. Szilvassy, M.L. Guzman, D.S. Howard, A.L. Pettigrew, T. Meyerrose, R. Rossi, B. Grimes, D.A. Rizzieri, S.M. Luger and G.L. Phillips, The interleukin-3 receptor alpha chain is a unique marker for human acute myelogenous leukemia stem cells, Leukemia $\mathbf{1 4}$ (2000), 1777-1784.

[58] S. Florian, K. Sonneck, A.W. Hauswirth, M.T. Krauth, G.H. Schernthaner, W.R. Sperr and P. Valent, Detection of molecular targets on the surface of CD34+/CD38- stem cells in various myeloid malignancies, Leuk Lymphoma 47 (2006), 207-222.

[59] L. Ponchio, E. Conneally and C. Eaves, Quantitation of the quiescent fraction of longterm culture-initiating cells (LTCIC) in normal human blood and marrow and the kinetics of their growth factor-stimulated entry into S-phase in vitro, Blood 86 (1995), 3314-3321.

[60] C. Eaves, J. Cashman and A. Eaves, Defective regulation of leukemic hematopoiesis in chronic myeloid leukemia, Leuk Res 22 (1998), 1085-1096.

[61] T. Holyoake, X. Jiang, C. Eaves and A. Eaves, Isolation of a highly quiescent subpopulation of primitive leukemic cells in chronic myeloid leukemia, Blood 94 (1999), 2056-2064.

[62] T.L. Holyoake, X. Jiang, H.G. Jorgensen, S. Graham, M.J. Alcorn, C. Laird, A.C. Eaves and C.J. Eaves, Primitive quiescent leukemic cells from patients with chronic myeloid leukemia spontaneously initiate factor-independent growth in vitro in association with up-regulation of expression of interleukin-3, Blood 97 (2001), 720-728.

[63] A. Gratwohl, J. Hermans, D. Niederwieser, F. Frassoni, W. Arcese, G. Gahrton, G. Bandini, E. Carreras, J.P. Vernant, A. Bosi, T. de Witte, W.E. Fibbe, F. Zwaan, M. Michallet, T. Ruutu, A. Devergie, A. Iriondo, J. Apperley, J. Reiffers, B. Speck and J. Goldman, Bone marrow transplantation for chronic myeloid leukemia: long- term results, Bone Marrow Transplant 12 (1993), 509-516.

[64] A.S.M. Yong and J.M. Goldman, Relapse of chronic myeloid leukaemia 14 years after allogeneic bone marrow transplantation, Bone Marrow Transplant 23 (1999), 827-828.

[65] S.M. Graham, H.G. Jorgensen, E. Allan, C. Pearson, M.J. Alcorn, L. Richmond and T.L. Holyoake, Primitive, quiescent, Philadelphia-positive stem cells from patients with chronic myeloid leukemia are insensitive to STI571 in vitro, Blood 99 (2002), 319-325.

[66] M. Copland, A. Hamilton, L.J. Elrick, J.W. Baird, E.K. Allan, N. Jordanides, M. Barow, J.C. Mountford and T.L. Holyoake, Dasatinib (BMS-354825) targets an earlier progenitor population than imatinib in primary CML, but does not eliminate the quiescent fraction, Blood 107 (2006), 4532-4539.

[67] X. Jiang, A. Lopez, T. Holyoake, A. Eaves and C. Eaves, Autocrine production and action of IL-3 and granulocyte colony-stimulating factor in chronic myeloid leukemia, Proceedings of the National Academy of Sciences USA 96 (1999), 12804-12809.

[68] X. Jiang, M. Stuible, Y. Chalandon, A. Li, W. Y. Chan, W. Eisterer, G. Krystal, A. Eaves and C. Eaves, Evidence for a positive role of SHIP in the BCR-ABL-mediated transformation of primitive murine hematopoietic cells and in human chronic myeloid leukemia, Blood 102 (2003), 2976-2984. 
[69] J.W. Singer, A.Z. Arlin, V. Najfeld, J.W. Adamson, S.J. Kempin, B.D. Clarkson and P.J. Fialkow, Restoration of nonclonal hematopoiesis in chronic myelogenous leukemia (CML) following a chemotherapy-induced loss of the $\mathrm{Ph}^{1}$ chromosome, Blood 56 (1980), 356-360.

[70] C.J. Eaves, J.D. Cashman, S.D. Wolpe and A.C. Eaves, Unresponsiveness of primitive chronic myeloid leukemia cells to macrophage inflammatory protein $1 \alpha$, an inhibitor of primitive normal hematopoietic cells, Proceedings of the National Academy of Sciences USA 90 (1993), 12015-12019.

[71] J.D. Cashman, C.J. Eaves, A.H. Sarris and A.C. Eaves, MCP1 , not MIP- $1 \alpha$ is the endogenous chemokine that cooperates with TGF- $\beta$ to inhibit the cycling of primitive normal but not leukemic (CML) progenitors in long-term human marrow cultures, Blood 92 (1998), 2338-2344.

[72] J.D. Cashman, I. Clark-Lewis, A.C. Eaves and C.J. Eaves, Differentiation stage-specific regulation of primitive human hematopoietic progenitor cycling by exogenous and endogenous inhibitors in an in vivo model, Blood 94 (1999), 3722 3729.

[73] J. Cashman, I. Clark-Lewis, A. Eaves and C. Eaves, Stromalderived factor 1 inhibits the cycling of very primitive human hematopoietic cells in vitro and in NOD/SCID mice, Blood 99 (2002), 792-799.

[74] J. Cashman, B. Dykstra, I. Clark-Lewis, A. Eaves and C. Eaves, Changes in the proliferative activity of human hematopoietic stem cells in NOD/SCID mice and enhancement of their transplantability after in vivo treatment with cell cycle inhibitors, J Exp Med 196 (2002), 1141-1149.

[75] J.D. Cashman, A.C. Eaves and C.J. Eaves, Granulocytemacrophage colony-stimulating factor modulation of the inhibitory effect of transforming growth factor- $\beta$ on normal and leukemic human hematopoietic progenitor cells, Leukemia 6 (1992), 886-892.

[76] G.K. Sing, J.R. Keller, L.R. Ellingsworth and F.W. Ruscetti, Transforming growth factor $\beta$ selectively inhibits normal and leukemic human bone marrow cell growth in vitro, Blood 72 (1988), 1504-1511.

[77] X. Jiang, Y. Zhao, C. Smith, M. Gasparetto, A. Turhan, A. Eaves and C. Eaves, Chronic myeloid leukemia stem cells possess multiple unique features of resistance to BCR-ABL targeted therapies, Leukemia 21 (2007), 926-935.

[78] X. Jiang, K. M. Saw, A. Eaves and C. Eaves, Instability of BCR-ABL Gene in Primary and Cultured Chronic Myeloid Leukemia Stem Cells, J Natl Cancer Inst 99 (2007), 680693.

[79] S. Flamant and A.G. Turhan, Occurrence of de novo ABL kinase domain mutations in primary bone marrow cells after BCR-ABL gene transfer and Imatinib mesylate selection, Leukemia 19 (2005), 1265-1267.

[80] M. Koptyra, R. Falinski, M. O. Nowicki, T. Stoklosa, I. Majsterek, M. Nieborowska-Skorska, J. Blasiak and T. Skorski, $\mathrm{BCR} / \mathrm{ABL}$ kinase induces self-mutagenesis via reactive oxygen species to encode imatinib resistance, Blood 108 (2006), 319-327.

[81] C.H. Jamieson, L.E. Ailles, S.J. Dylla, M. Muijtjens, C. Jones, J.L. Zehnder, J. Gotlib, K. Li, M.G. Manz, A. Keating, C.L. Sawyers and I.L. Weissman, Granulocyte-macrophage progenitors as candidate leukemic stem cells in blast-crisis CML, N Engl J Med 351 (2004), 657-667.

[82] T. Oda, C. Heaney, J.R. Hagopian, K. Okuda, J.D. Griffin and B.J. Druker, Crkl is the major tyrosine-phosphorylated protein in neutrophils from patients with chronic myelogenous leukemia, J Biol Chem 269 (1994), 22925-22928.
[83] J. ten Hoeve, R.B. Arlinghaus, J.Q. Guo, N. Heisterkamp and J. Groffen, Tyrosine phosphorylation of CRKL in Philadelphia $^{+}$leukemia, Blood 84 (1994), 1731-1736.

[84] G.L. Nichols, M.A. Raines, J.C. Vera, L. Lacomis, P. Tempst and D.W. Golde, Identification of CRKL as the constitutively phosphorylated $39-\mathrm{kD}$ tyrosine phosphoprotein in chronic myelogenous leukemia cells, Blood 84 (2004), 2912-2918.

[85] D.J. Barnes, D. Palaiologou, E. Panousopoulou, B. Schultheis, A.S. Yong, A. Wong, L. Pattacini, J.M. Goldman and J.V. Melo, Bcr-Abl expression levels determine the rate of development of resistance to imatinib mesylate in chronic myeloid leukemia, Cancer Res 65 (2005), 8912-8919.

[86] I.K. Hariharan, J.M. Adams and S. Cory, BCR-ABL oncogene renders myeloid cell line factor independent: Potential autocrine mechanism in chronic myeloid leukemia, Oncogene Res 3 (1988), 387-399.

[87] C. Sirard, P. Laneuville and J. Dick, Expression of bcr-abl abrogates factor-dependent growth of human hematopoietic M07E cells by an autocrine mechanism, Blood 83 (1994), 1575-1585.

[88] X. Jiang, W. Eisterer, Y. Zhao, N. Harada, C. Porada, G. Almeida-Porada, E. Zanjani, A. Eaves and C. Eaves, Longterm engraftment and persistence of slowly expanding populations of BCR-ABL+ human cells in sheep transplanted in utero 3 years previously with CML cells, Blood 100 (Suppl 1)(2002), 367a.

[89] Y. Chalandon, X. Jiang, S. Loutet, A.C. Eaves and C.J. Eaves, Growth autonomy and lineage switching in BCRABL-transduced human cord blood cells depend on different functional domains of BCR-ABL, Leukemia 18 (2004), 1006-1012.

[90] X. Jiang, E. Ng, C. Yip, W. Eisterer, Y. Chalandon, M. Stuible, A. Eaves and C.J. Eaves, Primitive interleukin 3 null hematopoietic cells transduced with BCR-ABL show accelerated loss after culture of factor-independence in vitro and leukemogenic activity in vivo, Blood 100 (2002), 3731-3740.

[91] X. Zhang and R. Ren, BCR-ABL efficiently induces a myeloproliferative disease and production of excess interleukin3 and granulocyte-macrophage colony-stimulating factor in mice: a novel model for chronic myelogenous leukemia, Blood 92 (1998), 3829-3840.

[92] S. Li, R.L. Ilaria, R.P. Million, G.Q. Daley and R.A. Van Etten, The p190, p210 and p230 forms of the BCR/ABL oncogene induce a similar chronic myeloid leukemia-like syndrome in mice but have different lymphoid leukemogenic activity, J Exp Med 189 (1999), 1399-1412.

[93] D.G. Peters, K.M. Klucher, R.C. Perlingeiro, S.K. Dessain, E.Y. Koh and G.Q. Daley, Autocrine and paracrine effects of an ES-cell derived, BCR/ABL- transformed hematopoietic cell line that induces leukemia in mice, Oncogene 20 (2001), 2636-2646.

[94] P.W. Zandstra, E. Conneally, A.L. Petzer, J.M. Piret and C.J. Eaves, Cytokine manipulation of primitive human hematopoietic cell self-renewal, Proceedings of the National Academy of Sciences USA 94 (1997), 4698-4703.

[95] H.G. Jorgensen, M. Copland, E.K. Allan, X. Jiang, A. Eaves, C. Eaves and T.L. Holyoake, Intermittent exposure of primitive quiescent chronic myeloid leukaemia cells to granulocyte colony-stimulating factor in vitro promotes their elimination by imatinib mesylate, Clin Cancer Res 12 (2006), 626-633.

[96] Y. Wang, D. Cai, C. Brendel, C. Barett, P. Erben, P.W. Manley, A. Hochhaus, A. Neubauer and A. Burchert, Adaptive secretion of granulocyte-macrophage colony-stimulating fac- 
tor (GM-CSF) mediates imatinib and nilotinib resistance in BCR/ABL+ progenitors via JAK-2/STAT-5 pathway activation, Blood 109 (2007), 2147-2155.

[97] E.R. Lepper, K. Nooter, J. Verweij, M.R. Acharya, W.D. Figg and A. Sparreboom, Mechanisms of resistance to anticancer drugs: the role of the polymorphic $\mathrm{ABC}$ transporters $\mathrm{ABCB} 1$ and ABCG2, Pharmacogenomics 6 (2005), 115-138.

[98] C.W. Scharenberg, M.A. Harkey and B. Torok-Storb, The ABCG2 transporter is an efficient Hoechst 33342 efflux pump and is preferentially expressed by immature human hematopoietic progenitors, Blood 99 (2002), 507-512.

[99] P.M. Chaudhary and I.B. Roninson, Expression and activity of P-glycoprotein, a multidrug efflux pump, in human hematopoietic stem cells, Cell 66 (1991), 85-94.

[100] H. Dai, P. Marbach, M. Lemaire, M. Hayes and W.F. Elmquist, Distribution of STI-571 to the brain is limited by P-glycoprotein-mediated efflux, J Pharmacol Exp Ther 304 (2003), 1085-1092.

[101] A. Hamada, H. Miyano, H. Watanabe and H. Saito, Interaction of imatinib mesilate with human P-glycoprotein, $J$ Pharmacol Exp Ther 307 (2003), 824-828.

[102] F.X. Mahon, F. Belloc, V. Lagarde, C. Chollet, F. MoreauGaudry, J. Reiffers, J.M. Goldman and J.V. Melo, MDR1 gene overexpression confers resistance to imatinib mesylate in leukemia cell line models, Blood 101 (2003), 2368-2373.

[103] T. Illmer, M. Schaich, U. Platzbecker, J. Freiberg-Richter, U. Oelschlagel, M. von Bonin, S. Pursche, T. Bergemann, G. Ehninger and E. Schleyer, P-glycoprotein-mediated drug efflux is a resistance mechanism of chronic myelogenous leukemia cells to treatment with imatinib mesylate, Leukemia 18 (2004), 401-408.

[104] H. Rumpold, A.M. Wolf, K. Gruenewald, G. Gastl, E. Gunsilius and D. Wolf, RNAi-mediated knockdown of Pglycoprotein using a transposon-based vector system durably restores imatinib sensitivity in imatinib-resistant CML cell lines, Exp Hematol 33 (2005), 767-775.

[105] N. Widmer, S. Colombo, T. Buclin and L.A. Decosterd, Functional consequence of MDR1 expression on imatinib intracellular concentrations, Blood 102 (2003), 1142.

[106] P.T. Ferrao, M.J. Frost, S.P. Siah and L.K. Ashman, Overexpression of P-glycoprotein in K562 cells does not confer resistance to the growth inhibitory effects of imatinib (STI571) in vitro, Blood 102 (2003), 4499-4503.

[107] Y. Zong, S. Zhou and B.P. Sorrentino, Loss of P-glycoprotein expression in hematopoietic stem cells does not improve responses to imatinib in a murine model of chronic myelogenous leukemia, Leukemia 19 (2005), 1590-1596.

[108] P.J. Houghton, G.S. Germain, F.C. Harwood, J.D. Schuetz, C.F. Stewart, E. Buchdunger and P. Traxler, Imatinib mesylate is a potent inhibitor of the ABCG2 (BCRP) transporter and reverses resistance to topotecan and $\mathrm{SN}-38$ in vitro, Cancer Res 64 (2004), 2333-2337.

[109] H. Burger, H. van Tol, A. W. Boersma, M. Brok, E.A. Wiemer, G. Stoter and K. Nooter, Imatinib mesylate (STI571) is a substrate for the breast cancer resistance protein (BCRP)/ABCG2 drug pump, Blood 104 (2004), 2940-2942.

[110] H. Burger, H. van Tol, M. Brok, E.A. Wiemer, E.A. de Bruijn, G. Guetens, G. de Boeck, A. Sparreboom, J. Verweij and K. Nooter, Chronic imatinib mesylate exposure leads to reduced intracellular drug accumulation by induction of the ABCG2 (BCRP) and ABCB1 (MDR1) drug transport pumps, Cancer Biol Ther 4 (2005), 747-752.

[111] T. Nakanishi, K. Shiozawa, B.A. Hassel and D.D. Ross, Complex interaction of BCRP/ABCG 2 and imatinib in BCR-
ABL-expressing cells: BCRP-mediated resistance to imatinib is attenuated by imatinib-induced reduction of BCRP expression, Blood 108 (2006), 678-684.

[112] N.E. Jordanides, H.G. Jorgensen, T.L. Holyoake and J.C. Mountford, Functional ABCG2 is over-expressed on primary CML CD34+ cells and is inhibited by imatinib mesylate, Blood 108 (2006), 1370-1373.

[113] A.H. Schinkel, U. Mayer, E. Wagenaar, C.A. Mol, L. van Deemter, J.J. Smit, M.A. van der Valk, A.C. Voordouw, H. Spits, O. van Tellingen, J.M. Zijlmans, W.E. Fibbe and P. Borst, Normal viability and altered pharmacokinetics in mice lacking mdr1-type (drug-transporting) P-glycoproteins, Proceedings of the National Academy of Sciences USA 94 (1997), 4028-4033.

[114] S. Zhou, J.J. Morris, Y. Barnes, L. Lan, J.D. Schuetz and B.P. Sorrentino, Bcrp1 gene expression is required for normal numbers of side population stem cells in mice and confers relative protection to mitoxantrone in hematopoietic cells in vivo, Proceedings of the National Academy of Sciences USA 99 (2002), 12339-12344.

[115] D.L. White, V.A. Saunders, P. Dang, J. Engler, A.C. Zannettino, A.C. Cambareri, S.R. Quinn, P.W. Manley and T.P. Hughes, OCT-1 mediated influx is a key determinant of the intracellular uptake of imatinib but not nilotinib (AMN107); reduced OCT-1 activity is the cause of low in vitro sensitivity to imatinib, Blood 108 (2006), 697-704.

[116] J. Thomas, L. Wang, R.E. Clark and M. Pirmohamed, Active transport of imatinib into and out of cells: implications for drug resistance, Blood 104 (2004), 3739-3745.

[117] L.C. Crossman, B.J. Druker, M.W. Deininger, M. Pirmohamed, L. Wang and R.E. Clark, hOCT 1 and resistance to imatinib, Blood 106 (2005), 1133-1134.

[118] X. Jiang, Z. Hanna, M. Kaouass, L. Girard and P. Jolicoeur, Ahi-1, a novel gene encoding a modular protein with WD40repeat and SH3 domains, is targeted by the Ahi-1 and Mis-2 provirus integrations, J Virol 76 (2002), 9046-9059.

[119] Y. Poirier, C.A. Kozak and P. Jolicoeur, Identification of a common helper provirus integration site in Abelson murine leukemia virus-induced lymphoma DNA, J Virol 62 (1988), 3985-3992.

[120] L. Villeneuve, X. Jiang, C. Turmel, C.A. Kozak and P. Jolicoeur, Long-range mapping of Mis-2, a common provirus integration site identified in murine leukemia virus-induced thymomas and located 160 kilobase pairs downstream of Myb, J Virol 67 (1993), 5733-5739.

[121] L. Girard, Z. Hanna, N. Beaulieu, C.D. Hoemann, C. Simard, C.A. Kozak and P. Jolicoeur, Frequent provirus insertional mutagenesis of Notch1 in thymomas of $\mathrm{MMTV}^{\mathrm{D}} / \mathrm{myc}^{\mathrm{m}}$ transgenic mice suggests a collaboration of c-myc and Notchl for oncogenesis, Genes Dev 10 (1996), 1930-1944.

[122] Y. Haupt, W.S. Alexander, G. Barri, S.P. Klinken and J.M. Adams, Novel zinc finger gene implicated as myc collaborator by retrovirally accelerated lymphomagenesis in Exuumyc transgenic mice, Cell 65 (1991), 753-763.

[123] M. van Lohuizen, S. Verbeek, B. Scheijen, E. Wientjens, H. van der Gulden and A. Berns, Identification of cooperating oncogenes in E mu-myc transgenic mice by provirus tagging, Cell 65 (2002), 737-752.

[124] S.M. Blaydes, S.C. Kogan, B.T. Truong, D.J. Gilbert, N.A. Jenkins, N.G. Copeland, D.A. Largaespada and C.I. Brannan, Retroviral integration at the Epil locus cooperates with $\mathrm{Nfl}$ gene loss in the progression to acute myeloid leukemia, $J$ Virol 75 (2001), 9427-9434. 
[125] X. Jiang, Y. Zhao, W.Y. Chan, S. Vercauteren, E. Pang, S. Kennedy, F. Nicolini, A. Eaves and C. Eaves, Deregulated expression in $\mathrm{Ph}^{+}$human leukemias of AHI-1, a gene activated by insertional mutagenesis in mouse models of leukemia, Blood 103 (2004), 3897-3904.

[126] L. Zhou, A. Ringrose, A.E.-J. Lin and X. Jiang, Deregulated expression of a novel oncogene, Ahi-1, in murine hematopoietic cells confers a proliferative advantage in vitro and leukemogenic activity in vivo and enhances the effects of BCRABL, Blood 108 (Suppl 1)(2006), 119a.

[127] R. Kronenwett, U. Butterweck, U. Steidl, S. Kliszewski, F. Neumann, S. Bork, E.D. Blanco, N. Roes, T. Graf, B. Brors, R. Eils, C. Maercker, G. Kobbe, N. Gattermann and R. Haas, Distinct molecular phenotype of malignant CD34+ hematopoietic stem and progenitor cells in chronic myelogenous leukemia, Oncogene 24 (2005), 5313-5324.

[128] E. Diaz-Blanco, I. Bruns, F. Neumann, J. C. Fischer, T. Graef, M. Rosskopf, B. Brors, S. Pechtel, S. Bork, A. Koch, A. Baer, U.P. Rohr, G. Kobbe, A. Haeseler, N. Gattermann, R. Haas and R. Kronenwett, Molecular signature of CD34(+) hematopoietic stem and progenitor cells of patients with CML in chronic phase, Leukemia 21 (2007), 494-504.

[129] E.T. Penserga and T. Skorski, Fusion tyrosine kinases: a result and cause of genomic instability, Oncogene 26 (2007), 11-20.

[130] T. Skorski, Oncogenic tyrosine kinases and the DNA-damage response, Nat Rev Cancer 2 (2002), 351-360.

[131] C.M. Verfaillie, J.B. McCarthy and P.B. McGlave, Mechanisms underlying abnormal trafficking of malignant progenitors in chronic myelogenous leukemia, J Clin Invest 90 (1992), 1232-1241.

[132] R. Salgia, E. Quackenbush, J. Lin, N. Souchkova, M. Sattler, D.S. Ewaniuk, K.M. Klucher, G.Q. Daley, S.K. Kraeft, R. Sackstein, E.P. Alyea III, U.H. von Andrian, L.B. Chen, J.-C. Gutierrez-Ramos, A.-M. Pendergast and J.D. Griffin, The BCR/ABL oncogene alters the chemotactic response to stromal-derived factor-1 $\alpha$, Blood 94 (1999), 4233-4246.

[133] S. Ghaffari, G.J. Dougherty, P.M. Lansdorp, A.C. Eaves and C.J. Eaves, Differentiation - associated changes in CD44 isoform expression during normal hematopoiesis and their alteration in chronic myeloid leukemia, Blood 86 (1995), 2976-2985.

[134] D.S. Krause, K. Lazarides, U.H. von Andrian and R.A. Van Etten, Requirement for CD44 in homing and engraftment of BCR-ABL-expressing leukemic stem cells, Nat Med 12 (2006), 1175-1180.

[135] T. Holtschke, J. Lohler, Y. Kanno, T. Fehr, N. Giese, F. Rosenbauer, J. Lou, K.P. Knobeloch, L. Gabriele, J.F. Waring, M.F. Bachmann, R.M. Zinkernagel, H.C. Morse III, K. Ozato and I. Horak, Immunodeficiency and chronic myelogenous leukemia-like syndrome in mice with a targeted mutation of the ICSBP gene, Cell 87 (1996), 307-317.

[136] S.X. Hao and R. Ren, Expression of interferon consensus sequence binding protein (ICSBP) is downregulated in BcrAbl-induced murine chronic myelogenous leukemia-like disease and forced coexpression of ICSBP inhibits Bcr-Ablinduced myeloproliferative disorder, Mol Cell Biol 20 (2000), 1149-1161.

[137] U. Steidl, S. Bork, S. Schaub, O. Selbach, J. Seres, M. Aivado, T. Schroeder, U.P. Rohr, R. Fenk, S. Kliszewski, C. Maercker, P. Neubert, S.R. Bornstein, H.L. Haas, G. Kobbe, D.G. Tenen, R. Haas and R. Kronenwett, Primary human CD34+ hematopoietic stem and progenitor cells express functionally active receptors of neuromediators, Blood 104 (2004), 81-88.

[138] D. Soligo, F. Servida, D. Delia, E. Fontanella, G. Lamorte, L. Caneva, R. Fumiatti and D.G. Lambertenghi, The apoptogenic response of human myeloid leukaemia cell lines and of normal and malignant haematopoietic progenitor cells to the proteasome inhibitor PSI, Br J Haematol 113 (2001), 126-135.

[139] F. Servida, D. Soligo, D. Delia, C. Henderson, C. Brancolini, L. Lombardi and G.L. Deliliers, Sensitivity of human multiple myelomas and myeloid leukemias to the proteasome inhibitor I, Leukemia 19 (2005), 2324-2331.

[140] S. Salesse and C.M. Verfaillie, BCR/ABL-mediated increased expression of multiple known and novel genes that may contribute to the pathogenesis of chronic myelogenous leukemia, Mol Cancer Ther 2 (2003), 173-182.

[141] D.H. Lam and P.D. Aplan, NUP98 gene fusions in hematologic malignancies, Leukemia 15 (2001), 1689-1695.

[142] L.A. McLean, I. Gathmann, R. Capdeville, M.H. Polymeropoulos and M. Dressman, Pharmacogenomic analysis of cytogenetic response in chronic myeloid leukemia patients treated with imatinib, Clin Cancer Res 10 (2004), 155-165.

[143] O. Frank, B. Brors, A. Fabarius, L. Li, M. Haak, S. Merk, U. Schwindel, C. Zheng, M.C. Muller, N. Gretz, R. Hehlmann, A. Hochhaus and W. Seifarth, Gene expression signature of primary imatinib-resistant chronic myeloid leukemia patients, Leukemia 20 (2006), 1400-1407.

[144] R. Villuendas, J.L. Steegmann, M. Pollan, L. Tracey, A. Granda, E. Fernandez-Ruiz, L.F. Casado, J. Martinez, P. Martinez, L. Lombardia, L. Villalon, J. Odriozola and M.A. Piris, Identification of genes involved in imatinib resistance in CML: a gene-expression profiling approach, Leukemia $\mathbf{2 0}$ (2006), 1047-1054.

[145] A.S. Yong, R.M. Szydlo, J.M. Goldman, J.F. Apperley and J.V. Melo, Molecular profiling of $\mathrm{CD} 4^{+}$cells identifies low expression of $\mathrm{CD} 7$, along with high expression of proteinase 3 or elastase, as predictors of longer survival in patients with CML, Blood 107 (2006), 205-212.

[146] Y. Zhao, A. Raouf, D. Kent, J. Khattra, A. Delaney, A. Schnerch, J. Asano, H. MacDonald, C. Chan, S. Jones, M.A. Marra and C.J. Eaves, A modified PCR-LongSAGE protocol identifies novel transcripts in human $\mathrm{CD}_{3}{ }^{+}$bone marrow cells, Stem Cells 25 (2007), 1681-1689. 


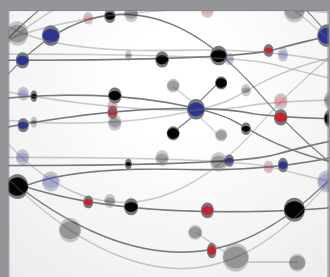

The Scientific World Journal
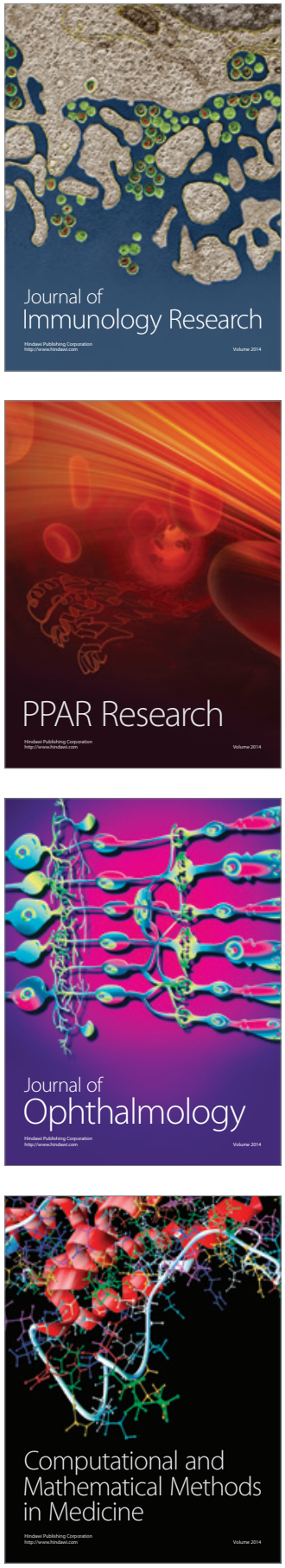

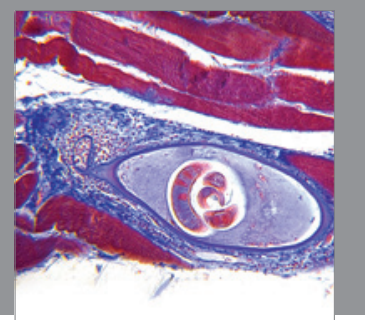

Gastroenterology

Research and Practice
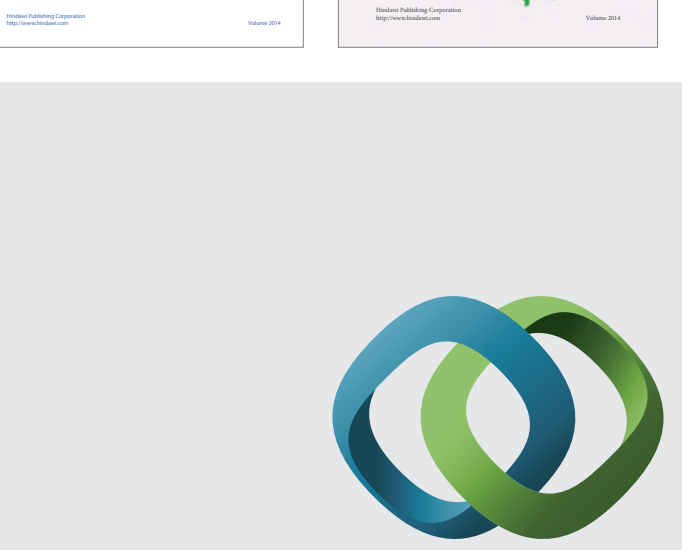

\section{Hindawi}

Submit your manuscripts at

http://www.hindawi.com
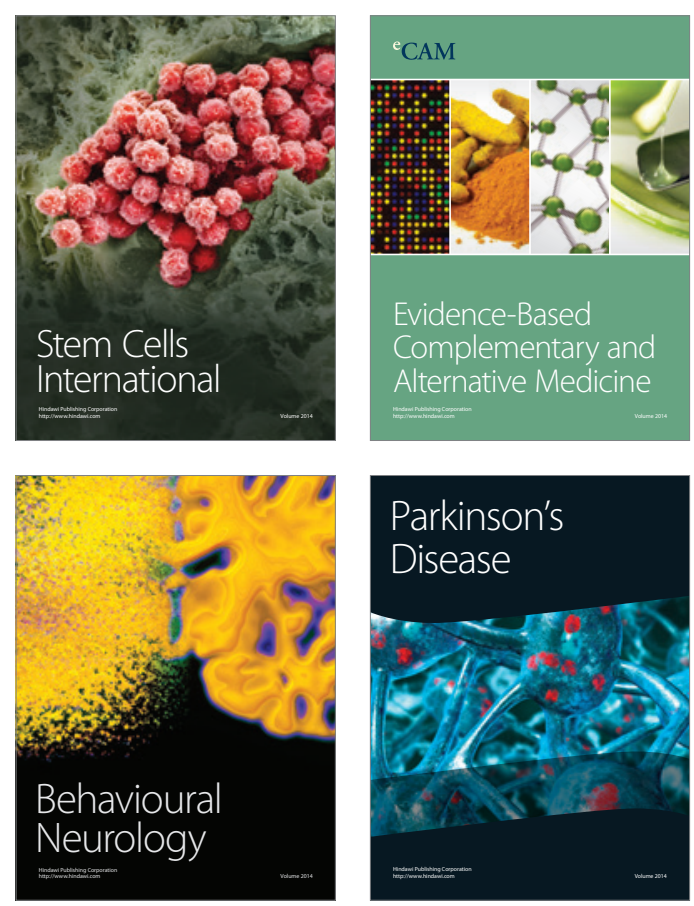

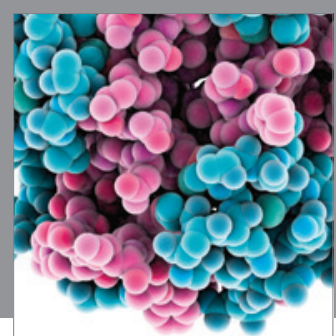

Journal of
Diabetes Research

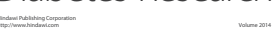

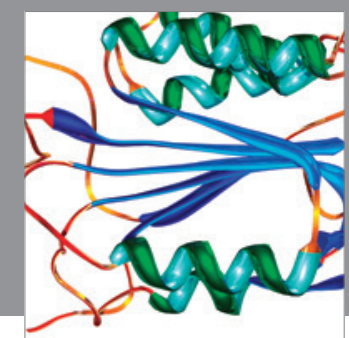

Disease Markers
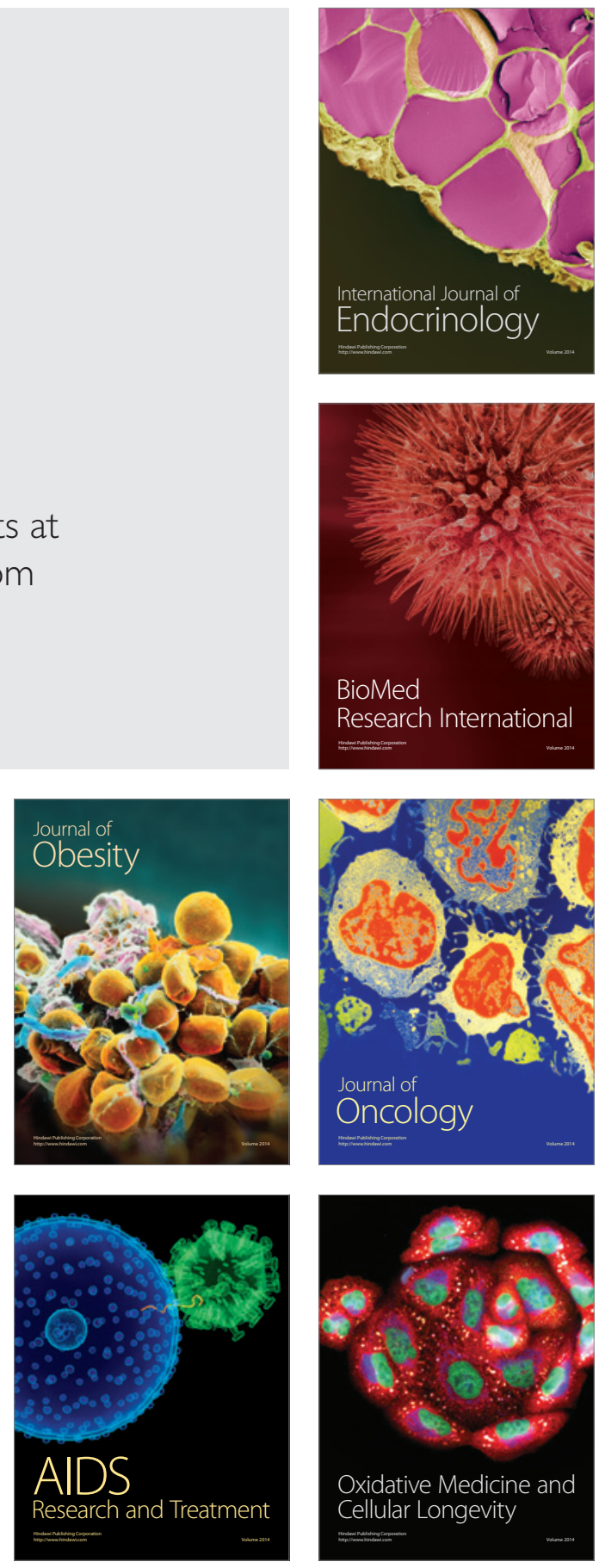